Illinois State University

ISU ReD: Research and eData

Theses and Dissertations

4-13-2021

\title{
"It Was Nice to Know I Wasn't the Only One Struggling:" Establishing Empathy and Communal Awareness Using Life Writing at the Middle Level
}

Kristin Danielle Reynolds

Illinois State University, kristin19reynolds@gmail.com

Follow this and additional works at: https://ir.library.illinoisstate.edu/etd

\section{Recommended Citation}

Reynolds, Kristin Danielle, "'It Was Nice to Know I Wasn't the Only One Struggling:" Establishing Empathy and Communal Awareness Using Life Writing at the Middle Level" (2021). Theses and Dissertations.

1465.

https://ir.library.illinoisstate.edu/etd/1465

This Thesis is brought to you for free and open access by ISU ReD: Research and eData. It has been accepted for inclusion in Theses and Dissertations by an authorized administrator of ISU ReD: Research and eData. For more information, please contact ISUReD@ilstu.edu. 
“IT WAS NICE TO KNOW I WASN'T THE ONLY ONE STRUGGLING:” ESTABLISHING EMPATHY AND COMMUNAL AWARENESS USING LIFE WRITING

AT THE MIDDLE LEVEL

\section{KRISTIN D. REYNOLDS}

88 Pages

This writing focuses on the social engagement of middle level students in the context of shared experience through the discussion of life writing. The study examines how empathy can be fostered and developed in the classroom based on two studies: one with an educator's former middle school students thinking back on the life writing performed in class and their comfortability level; the second involving those same high school students reflecting on their middle level education with their shared experiences involving life writing. The research results are compared to demonstrate how participants engage in their relationships with themselves and with academic peers and how this enriches the classroom experience overall. The research suggests that allowing students to choose to share life experiences through weekly writing can create an opportunity for middle level students to practice and develop empathy for others. This practice can be as beneficial for teachers as it is for their students and can make for smoother classroom management.

KEYWORDS: social engagement; middle level students; empathy; life writing; relationships; classroom experience 
“IT WAS NICE TO KNOW I WASN’T THE ONLY ONE STRUGGLING:” ESTABLISHING EMPATHY AND COMMUNAL AWARENESS USING LIFE WRITING

AT THE MIDDLE LEVEL

KRISTIN D. REYNOLDS

A Thesis Submitted in Partial

Fulfillment of the Requirements for the Degree of

MASTER OF SCIENCE

Department of English

ILLINOIS STATE UNIVERSITY 
(C) 2021 Kristin D. Reynolds 
“IT WAS NICE TO KNOW I WASN’T THE ONLY ONE STRUGGLING:” ESTABLISHING EMPATHY AND COMMUNAL AWARENESS USING LIFE WRITING

AT THE MIDDLE LEVEL

KRISTIN D. REYNOLDS

COMMITTEE MEMBERS:

Bob Broad, Chair

Robyn Seglem

Joyce Walker 


\section{ACKNOWLEDGMENTS}

This past year would have felt impossible without the support from others, let alone through the writing of this thesis. I would like to thank my advisor, Dr. Broad, for his endless supply of knowledge and his ever-present tranquil demeanor to keep my nerves in check.

A special thank you also to my committee members, Dr. Walker and Dr. Seglem, who have provided me with perspectives that I may not have considered due to my privileged lens along with all of our laughs and "aha moments" they've given me the opportunity to experience.

Gratitude in abundance goes to my coworkers as we've taught our middle school students during a global pandemic. The people I work with are akin to the hero of an epic tale with their superhuman abilities to adapt, create, prepare, and learn all the while supporting the mental health of our student body and each other. Morale may have been low, but our comradery was high.

The support from my partner, Thomas, throughout this entire year has been my grounding as I've struggled, concentrated, wrote, and argued with the universe. The amount of appreciation I have for his level of patience and empathy are immeasurable.

My family and friends, who have always supported my fascination with reading and the arts of language and composition.

My middle school and former students, whose curiosity, sense of humor, and innate ability to state the obvious has kept me on track with my writing. I can say with confidence that I 
have learned more from my students on the subtle arts of teaching than I would have thought possible. I can only hope that my students feel as though there was an even tradeoff. My final thank you goes to the Illinois State Writing Project which has given me the courage to attempt this thesis. With the valuable two years of collaborating with the memorable teachers who have experienced those three intense, fun-filled weeks of crying, laughing, and writing, I can finally state with confidence: "Yes, I am a writer."

K.D.R 


\section{CONTENTS}

$\begin{array}{lll}\text { Page } & \end{array}$

ACKNOWLEDGMENTS

CONTENTS

CHAPTER I: INTRODUCTION 1

CHAPTER II: REVIEW OF LITERATURE

CHAPTER III: METHODS \& METHODOLOGIES 30

$\begin{array}{ll}\text { Aims } & 30\end{array}$

Research Methods \& Explanations of Methods Chosen 32

$\begin{array}{ll}\text { Personal Observations } & 32\end{array}$

Prescriptive Language Addressed 32

$\begin{array}{ll}\text { Participants } & 33\end{array}$

$\begin{array}{ll}\text { Participant Questions } & 37\end{array}$

$\begin{array}{ll}\text { Data Gathering } & 40\end{array}$

Research Gathering Limitations $\quad 41$

$\begin{array}{ll}\text { Data Analysis } & 42\end{array}$

CHAPTER IV: FINDINGS

$\begin{array}{ll}\text { Data Gathering } & 45\end{array}$

Experiences of Empathy: Personal Experiences \& Emotionally Charged Stories $\quad 46$

Mutual Aid and Support - Not the Only One Struggling 49

Being Heard - Opening Students Up to Something New 50

Pressure to Share Writing in the Classroom - "I Like to Hear Others Talk First" 52

Willingness to Share Life Writing - Being on the Same Level as You 55 
Shift in Classroom Dynamics - Identifying Each Other's Passions

Moving Away from Egocentricity: Communal Awareness and Action

Relationship Among the Codes

Unexpected Findings Regarding Student Voice

Answering the Big Question

Designated Time

Modeled Behavior Expectations

Building Rapport

Teaching Applications

A Conversation: Putting the Findings to Research

Future Research

WORKS CITED

APPENDIX A: FIRST ROUND DATA GATHERING QUESTIONS 


\section{CHAPTER I: INTRODUCTION}

By $5^{\text {th }}$ period, the late April sunlight was pouring into my classroom washing the room in a warm, cozy light. My eighth graders could almost taste summer break approaching, yet they were mellow as they greeted me. We had gotten back into our routine and the swing of things after our Spring Break. As their language arts instructor, I always enjoyed this time of the year as the days got warmer and the light lasted longer. It was smooth sailing from here.

As we did on every Friday, I watched my students habitually walk through my door with a greeting and head to the plastic tubs on the far side of the classroom with their class period number labeled on the outside. They were fishing out their writing folders containing their journals and bar graphs before heading to their assigned seats. They were professionals at knowing the expectations by this point. My middle school students thrive on structure, though, I would argue, that not all of them would admit to it.

What made this day unusual was that a student, Alex, walked up to another student named Zachary. This was considered odd as they were more acquaintances than friends even though they had been in the same grade. And as I listened, I realized that I was also making a change in my classroom forever.

In a hushed voice, I heard Alex ask, "How is your mom doing? Has she gotten any better?"

"She's getting better." Zachary had answered quietly in response. "Thank you for asking about her." 
This was significant as a week earlier, on a Friday, Zachary had opened up during our writing and sharing time about his mom who had been diagnosed with cancer. I had not anticipated that this student would talk about it, let alone bring it up during a time to share in front of the class, yet he had chosen to do so. I didn't know these conversations were going to carry over into the next week. My students were showing compassion for their peers. It was then that I knew what life writing could do for my middle school classroom.

Even though there is a method for the writing process called Power Writing, this writing and sharing activity took on a whole different meaning at our middle school. Power Writing, at our school district, originally started as a way for the language arts instructors to get some quick writing data on our students in a rural town near the Decatur area in central Illinois. It was a way for our English Department to see how quickly students could write and check their sentence fluency in addition to words written per minute. This was designed to measure accuracy of writing goals for a lot of our IEP/504 students. There were a few things that instructors looked for specifically when this writing activity had first begun at the school district: Were students writing sentences that were cohesive and communicated their thoughts? Could students keep up with grammar as they wrote? Is their penmanship legible? This activity became a habit I got into doing with my seventh and eighth graders every Friday when I moved down to teach at the middle school from the high school beginning back in the fall of 2016.

I would ask an open-ended question for students to answer. Students were always allowed to freely write about something else if the question I had asked didn't jive with them that day. I would time my young writers for a minute as they wrote and scribbled, sometimes with great fervor as they tried to best their last week's word average. My students quickly became 
accustomed to my phone's catchy "ba-doop-de-doop” jingle. Students would finish the sentence they were writing and then only count the words that they had been able to write in that minute of time. From there, students would share how many words they were able to get in that one minute. At the beginning of the year, it could have only been fifteen words. By the end of the school year, some eighth graders were able to get into the forties or low fifties. ${ }^{1}$

Some students would share their numbers with an immense amount of pride if they had succeeded in increasing their number of words written in one minute. Students would then be asked to record that number on their personal bar graph. Sometimes students passively recorded lower numbers. By the end of the year, there was a neat bar graph for all my students to see their own work. Students could literally see the progress they were making in their sentence fluency. This bar graph data was then kept to show progress monitoring for many students who either had an IEP or a 504 plan. I had not anticipated the possibility that something more difficult to measure was about to capture my interest.

It wasn't until my third year of teaching language arts that I finally noticed the pattern that was occurring in my classroom when my middle level students did their life writing and sharing activity on Fridays. As an original way to get sentence fluency and writing sample data, I had only used it to serve as the bell ringer in my class and hadn't thought much about the activity otherwise. When students began to want to share more than just how many words they could write in a minute, I thought I was onto something. Not only were these comments coming from

\footnotetext{
${ }^{1}$ Power writing at the school district was originally used to see if students could write fluently under a timed session to serve as a universal screener to identify benchmarks for IEP/504 students. The continuation of the use of power writing developed into more content rather than number of words written per minute by the time of this study.
} 
my students' writing, but a lot of the feedback students would get from their initial comment would be that of concern on what a student shared that fostered relationship building. I continued to observe this transitional trend with great interest. My students seemed to start to care more about their peers from what they were learning about one another during this weekly bell ringer activity. When this shift occurred - from not being able to see any hands up to seeing multiple hands up in the air with fervent expressions - I knew some kind of transition in my classroom had occurred once more. One of the most significant pieces of evidence where I identified this shift was when my third hour was coming in and a student privately went up to another student before class to ask about how his mom was doing. It was the previous week that this student had shared with the class that his mom had been struggling with cancer. The student that had gone up to him was not in his typical friend group and these two had rarely spoken in class otherwise. It was becoming a pattern as the years went on. My first question was: What events occurred to inspire my students to share their writing? My immediate second question was: How can I ensure this transition takes place next year?

In my experience, my middle level students are apprehensive when it comes to sharing their writing. Sometimes sharing writing can make others feel vulnerable, and my students were no different. For many, it may be the concept of it being high risk. For others, it may be identified as a means to show vulnerability. All I knew was that my students were very anxious, sometimes even fearful, when it came to sharing their written work. I wouldn't force it, but it was noticeable from the instructor-side of things. It bothered me that it was my class making my students feel this apprehension. I could empathize with those emotions as I wasn't one to talk much at all during my middle school days, let alone read something that I had written to the 
possibly judgmental ears of my own peers. Could I encourage students to want to workshop, share, and talk about their own writing when I, myself, would have been hard pressed against talking about my own writing with my middle school language arts teacher?

One of the other major concerns was that many individuals don't know the power their words can inflict on others, and that includes painful remarks. This is something I am constantly focused on as middle level students are still developing cognitive empathy. How could I measure this observation? Could this shared experience of writing be the key to creating a more empathetic class, one whose peers genuinely cared about the wellbeing of their classmates, inspired through their own writing? Through the activity designed to measure sentence fluency, I'd realized I'd stumbled onto a new phenomenon in my class where my closed off students began to voluntarily share their writing with others. During my six years of teaching, I've watched this evolution occur in my classroom. It was time to do some research to identify what this transformation really was, along with what it could mean for other educators in writing. Had another educator already written about an experience similar to this one I was experiencing? It turns out that I wasn't the only teacher to attempt to study life writing being used in an ELA curriculum, which I found to be both encouraging and a relief. The problem was that there was little information on life writing with middle level students.

Many educators, including those who teach subjects outside of language arts, create environments for students to learn how to engage themselves in components of citizenship, or belonging, in their classroom. Nicole Mirra states that belonging begins with empathy which is provided within her book titled Educating for Empathy. "The most commonly understood definition for empathy is the one that Obama (2006) used in his speech - the ability to put 
yourself 'into another person's shoes' or to see the world from that person's perspective," (3). The data gathered in this study was promising in its evidence that the writing conducted in my classroom involving life writing and sharing did help students become more empathetic and aware of people around them.

I wanted to study this process, but was at a loss on where to begin. I was struggling with the concept of measuring data that was qualitative over quantitative. I could easily have looked at my students' bar graphs that they kept with their writing folders to see their numbers, tracking their words per minute that they recorded each week, but the type of data I was looking for was going to be more challenging to obtain. I came up with a series of open-ended questions for former students, now in high school, to answer as a means of reflecting on their experiences within our language arts classroom from when they were in middle school. After obtaining permission from IRB, my administrator at my school district, parents/guardians, and former students, I was ready to see what they had to say when thinking back on our class and the writing and sharing that had evolved over the course of their eighth grade school year. What they had to say left me with a retelling of my own teaching through the eyes of others and separate ideas on what we had thought made the shift in sharing occur within their writing.

At the beginning of the year, students would share their number of words per minute with me and the rest of the class, and we would move on into our lesson, but something began to evolve as the year went on. The numbers weren't what some of my students wanted to share. They began to share what was on their mind as they freely wrote or answered the open-ended question. Sometimes they would read directly from the text they had just written. Typically, this open-ended question would be: How are you? Students were suddenly sharing how nervous they 
were for basketball tryouts. I was hearing about the loss of a loved pet. Sometimes other students would begin to show sympathy and empathy for those who were going through these experiences some of them have shared. This was all without my prompting, other than the initial question to be written about. The activity was only meant to be a universal screener for students' writing, yet students were beginning to open up. How did this shift occur when this bell-ringer activity was only meant to serve as a measurement of writing fluency? I had to do some reflection on my entire course that I was teaching as one of my main focuses of being a language arts teacher was focused on written expression. The combination of these multiple questions continued to build until I began a shift in my pedagogy on how I viewed my classroom environment. Very quickly, this transformed into my big question: In a classroom designed to promote students' sense of community, agency, and voice, how did students create an empathetic community through the experiences of shared composition?

I decided to reach out to the Response to Intervention Specialist at my school district, Kathy Wimer. I wanted to ensure that I was still receiving the data that was desired if a universal screener for writing was asked for by RTI (Response to Intervention) ${ }^{2}$ or the SPED (Special Education) team. I was reminded that a universal screener is a way to quickly assess the student population to see if any student was beginning to fall behind while not qualifying for extra support through the SPED classes. "This was a way for my middle school team to identify students who are at risk and in need of more academic opportunity, to see who could be slipping

\footnotetext{
2 The response to intervention (RTI) is a process with the purpose of preventative care offered and given to students who are having difficulties in learning but don't always meet the requirements for Special Education accommodations. RTI serves as a preventative model to limit academic failure in at-risk students identified through scientific research-based interventions such as universal screeners. These universal screeners create benchmarks and help specialists set goals to provide practice for students to bridge the gap between their current skill level in an effort to bring students up to grade level standards.
} 
through the cracks. It's more difficult now to do that with only the lowest $10 \%$ of students being qualified for Special Ed," (Wimer).

As I was interested in exploring power writing further than just the number of words students could write in one minute, I decided to talk to the SPED instructors to see if I could use the data that I was studying in addition to maintaining our charts that measured words per minute. Our two special education teachers encouraged my study in addition to my middle school team and administrator. I knew I didn't want to interfere with the data for determining students who qualified for RTI, but I was sure there was more data that could be gathered from our weekly bell ringer activity having to do with the quality and content of the writing over the quantitative amount of writing that was occurring. The encouragement from both SPED teachers stemmed from wanting students to be invested in what they were writing and thought it would be good for all of our students to get more practice in both writing and then discussing the content of what they wrote about.

With the RTI Action Network serving as a way to, "guide educators and families in the large-scale implementation of RTI so that each child has access to quality instruction and that struggling students - including those with learning and attention issues - are identified early and receive the necessary support to be successful," (Feldman). I knew I would be continuing this form of activity in my classroom as it was used to help identify students who needed help. Due to this, I wanted to extend the meaning of this activity in my classroom to see if the phenomenon I had identified could be duplicated and refined to provide students experience in building emotional and social bonds with one another continuously every school year. As long as I was still getting my universal screener numbers on our timed writing, I was given the green light by 
my district to push forward with my studies. This was also helped by the fact that I wasn't going to be pulling the data for my study from my current students.

With help from the reviewers at the Illinois State University Institutional Review Board, I was able to create a series of questions that were intentionally left open-ended to encourage students to elaborate on experiences when thinking back to their seventh and eighth grade language arts class. I decided I wasn't going to be able to ask my current students at the time. I didn't want to pressure my middle level students as I was still in a position of power over them regarding their grade and what occurred in the classroom. I wanted my former students to assist me in this study as I would no longer be in that position of power over them regarding grades. These students would have already consented to wanting to answer a few questions for me by their own choice. I believed that my current students could potentially skew the data as they would want to get a good grade on what would have been an ungraded assignment or feel forced into providing an answer that would distort the true feelings of the class. This is an additional reason I did not pursue data from students who were currently my middle level students for this case study.

With my former students now in high school, I thought they would be able to reflect back on our shared writing experience. I was ready to hear it - the good and the bad - to see if they had noticed anything from their student-lensed view of the writing that had taken place in our classroom. To keep things in perspective and prevent me from being overwhelmed by data, I decided to continue with only five of my previous students as a means of gathering this written data. I selected these students as individuals who had strong personalities in my class. Please note that this does not necessarily mean that they were loud or obtuse, but they were memorable 
students who I knew I had developed a rapport with when I had them in middle school. The reason they were chosen was due to students being willing to help in addition to these students being able to handle the writing being asked of them on top of their regular schoolwork which is why these students were approached about being a part of the study. These five individuals range from sophomores to senior level as of the Fall 2020-2021 school year.

In the next section of my thesis, I'll be looking at the work of scholars, paraprofessionals and educators on the topic of building empathy, a sense of belonging, and asking students to take ownership of their writing. I will be explaining my methods and methodologies of how I decided to go about planning, obtaining, and comparing the data provided on student reflections to see if there were observations similar or dissimilar to what I had observed as their former teacher. From there, I will be providing the answers from my former students and the patterns I noticed within their self-reflective writing. The conclusion of the separate perspectives of both myself as an educator along with my students as we went through this process is highlighted by my own self-reflection on this process and the data involved. 


\section{CHAPTER II: REVIEW OF LITERATURE}

As research began for this study, I was alarmed to find very little data or studies having to do with middle school students in connection to empathy or life writing. Overall, it's important to note that I was not able to locate a single study that connected middle school language arts students to empathy through life writing. As a result, some of the research will be dated as I strived to locate other studies that had taken place having to do with empathy or writing for students at different levels in their schooling. Furthermore, the information that was located came from sources that I was able to connect to my own classroom. Regardless, there is a significant gap in research on the topic surrounding middle school writing in connection to empathy. It is the hope that this research is the beginning of an effort to begin to bridge this gap.

There seems to be a transitionary period between elementary school to the middle school where students become reserved and very particular about what type of writing they feel comfortable sharing with the class. This is seen as a stressful time for both parents and students at this age. This is brought up in Middle School Journal in the article, "Transition to a Middle Level School: What Kids Say." Arowosafe and Irvin remind educators that, "Not only do students making the transition experience stress (Fenzel, 1989), but many parents are anxious and concerned about the welfare of their children during this stage of development, (Baker \& Stevenson, 1986)" (15). This suggests that the transition from middle school is identified as stressful because the transition is seen as happening on multiple levels: physical, social, mental, emotional, and academic. These multiple transitions can exacerbate stress in middle level students.

How can I help my students feel more comfortable with the idea of sharing their written thoughts and ideas? Writing can be scary and intimidating for all writers, especially at the middle 
level when the invisible audience is a constant presence. "The concept [invisible audience] derives from Piaget's (1969) theoretical expectation that adolescents will manifest relatively greater self-consciousness than either younger children or adults due to the egocentrism coincident with formal operational thinking" (Kelly et al. 897). It is important to keep in mind that students at the middle level may display actions of hesitancy with sharing due to this invisible audience in addition to the very real audience in the classroom. Writing is an extension of oneself, and for some, that may be the most intimidating component. However, there is incredible educational value to sharing writing with peers that can help establish this sense of belonging. When students do not feel as though they belong, they may feel more comfortable avoiding a class or school altogether. "Students with chronic absences tend to struggle academically and may not benefit fully from all school has to offer. A positive school climate has been shown to reduce absenteeism and promote academic success" (Daily et al.). If students look forward to a class or know that they have a space and time dedicated to allowing their voices to be heard could positively impact a student to contribute to a positive learning climate for all students.

Furthermore, in order for students to feel comfortable sharing, there needs to be the desire to share or for their writing to feel authentic. Nadia Behizadeh, in her article, "Aiming for Authenticity: Successes and Struggles of an Attempt to Increase Authenticity in Writing," discusses how creating assignments that students see as authentic can increase student engagement. I was interested in creating writing assignments for middle level students that felt genuinely valuable to students in order to see an increase in student engagement.

In her article focusing on the successes and struggles of educator's trying to figure out how to create this type of student engagement: 
In past conceptions, a key issue is that teachers and/ or researchers determined authenticity. In a critique of a "real world" defined by educators or researchers, Splitter (2009) refined authenticity to mean that students need to be persuaded of the connection between what they do in school and how they perceive the world, and the connection needs to be meaningful to the individual student. Drawing on the idea of authenticity as subjective, I define authenticity in writing as students' perception that a writing task connects to their life, that the task is meaningful to them and connects to their experiences, culture, interests, and goals (58).

My theoretical assumptions began with believing that students sharing compositions assisted in students displaying levels of empathy to one another while also exposing students to authentic writing assignments. Sharing compositions can encourage students to take ownership of their work and seek out ways to continue to share their voice through their writing quickly became another theoretical assumption. Lastly, I was encouraged to see that students seemed to become more accepting of others after sharing more about their lifestyles, backgrounds, and personal lives without my prompting after continuously sharing life writing in the classroom.

I was particularly interested in life writing as I had observed that, when my students would begin to open up, it would be a story about their lives. Sometimes these stories had happy components while others had the opposite. Students began to build on what a previous student may have said which fostered even more students willing to raise their hand and contribute. This trend of sharing life stories made me think that life writing scholars might have something to add to my investigation.

Sidonie Smith and Julia Watson's book supports my pedagogical argument on life writing and how it can make a significantly large impact on a writer's life. Their book titled 
Reading Autobiography: A Guide for Interpreting Life Narratives, served as a means to focus on various forms of life writing and their impacts. According to Smith and Watson, the elements of life writing include: memory, identity, experiences, embodiment of space, and agency for the writer. Autobiographies, memoirs, and the visual-verbal-virtual ways to life writers are discussed in the traditional sense of writing with a pen and pencil or typing while also introducing using a new way of recording one's narrative. Using audio recording devices, webcams, or social media are also seen as ways of incorporating and recording life writing in new virtual platforms.

In chapter five, "In the Wake of a Memoir Boom," Smith and Watson states that, "In this age of pervasive communication and the online circulation of private emotions, new modes of memorialization and vulnerability to loss register transient grief in more public forms that the family album traditionally did" (138). The therapeutic value seen within these types of writing helped support my claim that life writing can get people through difficult times, including my students. My argument is that students find a way to make their writing feel authentic. In doing so, my students began to develop a more empathetic response to hearing each other's life stories. Sharing stories, although good for the writer, according to Smith and Watson, I argue that it is additionally helpful for the listeners as well.

In a study focused on writing about families and sharing the composition with small groups, Dr. Lawrence Rosenfeld identified a few observations. Although students identified the work as being educational, there was hesitation in the sharing aspect of the project. Additionally, there were concerns about the technicalities of the assignment. The main point, arguably the most important observation, was: "The third most pronounced outcome from the narrative assignment related to social support, which emerged from the content analysis as "bonding." Specifically, students described receiving several types of social support (Richman, Rosenfeld, \& 
Hardy, 1993), including emotional support (comfort, caring), reality confirmation support (confirmation of the storyteller's perceptions of reality), and task appreciation support (acknowledgment of the value of the story)" (17). This type of sharing is what I typically reserved for the weekly writing activity on Fridays. "This would allow at-risk students to become experts on their chosen topics, giving them a renewed confidence in their personal knowledge" (Galati 14). If students see no value in sharing a part of themselves through their writing, then they can feel vulnerable and not trust how peers may respond to their shared piece of writing.

In 2014, there was an article published titled "Beyond the Author's Chair: Expanding Sharing Opportunities in Writing" by Anna H. Hall. The article discusses sharing as part of the writing process while focusing on various avenues students can take to share their writing. The part of the article that interested me the most asked why certain students enjoy sharing while others remained reluctant. "Sharing has also been found to help children develop a sense of community, foster connections between home and school experiences, and assist students in negotiating their social worlds (Cazden, 1985; Dyson, 1993; Lensmire, 1992). For example, when children share stories about their family traditions, they may recognize cultural similarities and differences that they have with their peers. This exchange of personal information among classmates can help nurture appreciation and acceptance, as well as broaden and deepen children's initial constructions of written language and help build collective meaning among peers (Barone, 2013)" (Hall). This is exactly the reason that I have continued with the writing exercise for as long as I've been teaching middle school. The trick was trying to refine it continuously each year without accidentally messing up the fragile chemistry that was occurring with my students. In a way, I was afraid I would jinx myself by tampering with what was already working in my classroom. Regardless, I continued to open up the opportunities for students to 
share, adjusted the time allowed in class depending on the amount of conversation going on, or provided extra time to one specific question if it seemed especially important to students as they began to open up or provide a student the kairos needed to seize an opportunity to speak. As for the students who don't want to share, I do not force it. They will eventually share when they are ready. For some students, that may mean after class when students are leaving and they run up to quietly share with me. That's okay. Although Hall discusses the benefits of students sharing, it's best when students are encouraged, inspired, or moved to share on their own. One of the most important elements of my activity was the first question: How are you? This seemed to be the question that would need the most time dedicated to discussion. Again, students would open up and share more on their own as the school year went on and the practice of sharing became more common within the classroom. A couple of participants commented on this, stating that they felt more comfortable with talking after other students had gone first. Some students would comment on their physical health while others wrote about stressors in their life connected to mental health. Sometimes students would write about what they were looking forward to. As a result, I would always keep my first question of the three as a question about how my students were doing. This also created a record of a student's school year that showed them how they were doing throughout the entire school year. The other questions asked week by week would be more lighthearted and creative or connected to main ideas that we had been focusing on within our class.

With the intention of building a strong rapport with my students, I can justify spending half of our class time on Fridays dedicated to this writing and sharing activity. The importance of having the teacher model and reinforce the audience's behavior is brought up in the article as well. "Teachers should model polite questions and comments as well as discuss comments that 
might hurt others' feelings" (Hall). By being an active listener in my own class, I can model my expectations for my own students. I am careful to listen to what my student is sharing and then I am sure to respond to them in a way so that my student knows that they were heard. I want the focus to remain around the listener. This prevents students from automatically wanting to share a story that dominates or takes over from the initial speaker. Students can quickly learn what is an appropriate comment to a student that has been shared by hearing what the teacher has to say in response to another student's shared writing. This includes when it's a good time to connect to a story with a story of their own.

Dr. Brianna Kennedy made some observations in a study conducted on middle level disaffected students that had been formerly expelled. The focus of the study was to identify the practices of the most and least effective teachers at the institution. The main focus surrounded the significance of building positive rapport with students. Dr. Kennedy mentioned one of the more successful teachers with the acknowledgement, "Mr. Springer used his knowledge of students' interests to choose curricular materials that engaged students. He built trust with them so that they felt comfortable sharing their difficulties and anxieties with him, and he used his awareness of students' states of mind to inform his classroom management decisions" (34). In my own classroom, I found that the process of getting to know students and establishing trust took a significant amount of time. In fact, most of my students would wait at least a quarter into the school year before opening up, especially if it was their first year with me as their teacher. Giving students time to build a relationship with the instructor seems to give students the most confidence once a positive rapport has been established. Once students felt comfortable, it made the fourth quarter quite engaging with how many students had opened up over time and now wanted to contribute or connect to the class discussion with their own writing contribution. One 
element of my success in this practice is that the activity is always consistent, throughout the year, every Friday, which may have allowed my students to trust me, and each other, with their stories. Because the practice became a part of our routine, a habit, students became accustomed to the structure and trusted the class more as the activity became more familiar and predictable to them.

In "Spirit of Healing Group: Safety in Storytelling," Barbara McNish states, "Building trust and intimacy, setting up boundaries, and teaching mindfulness is essential for safety within a group. The steps of safety, trust building and intimacy, overcoming old messages, and sharing feelings are part of the process that supports healing and recovery" (41). The entire exercise is on building trust with those who are constantly close by. When a student is with the same group of students for years, feelings develop, which can build connections and can put stress on classroom dynamics. Most of this is due to the fact that the teacher does not know what kind of relationships have already been established between students in the classroom at the beginning of the school year. With pathos being addressed and shared between students, I believe the direct result of this storytelling will create stronger bonds and strengthen emotional ties within the classroom through relatability, sympathy, and empathy for peers. It can be cathartic to retell an experience while others are listening, offering a platform for those who need to talk.

Furthermore, the type of writing focusing on grief could also be beneficial for the mental health of the writer by getting thoughts, feelings, memories, and emotions down on paper. It is with all of this in mind that it is worth noting that not all students may be comfortable sharing about experiences they've had, and that is okay. Forcing a student to share something that bothered them or not ready to share could lead to students not feeling valued or engaged in the classroom. Overall, this text focuses on autobiographical texts and how that writing experience 
can shape and reconstruct a narrative in a new and powerful way while being mindful and sensitive to students who may have experienced past trauma.

One of the reasons I tend to avoid forcing a student to share is due to my distaste for an authoritarian teaching style as it has not worked in the favor of many of my coworkers or myself when there has been the strict enforcing of obedience to authority with middle level students. It is necessary to give students a sense of autonomy and choice in the manner with structure and guidelines within my classroom, especially when it comes to students sharing any of their writing. In my early years as an educator, I noticed that telling a student "because I said so," really isn't the best approach to having any middle school student do what is asked of them. As frustrating as it can be, it is also normal for middle level students to have a sense of rebellion about them at this stage in their development. It's important that teachers recognize this and word their expectations carefully and be willing to explain why a task is being asked of a student so that it can be rationally explained without anger or frustration coming through.

This experience has led me to avoid more authoritative stances in my teaching pedagogy. It is the academic autonomy that I believe allows students to gain the confidence to discuss their work while being able to provide well thought out comments to other speakers. This approach to teaching can further support students and prevent the exacerbation of depression students may be struggling with according to a study focusing on teaching styles at the middle and secondary level for students suffering with depression. One of the conclusions in this study confirmed that, "Junior high students who perceived teaching styles as authoritarian were more depressed than those who perceived their teachers were indifferent, permissive and authoritative" (Yao 5). Providing students with the opportunity to share seems to be the most important step in my effort to discover how sharing writing is beneficial in the middle level language arts classroom. 
There is an argument to be made on the method of how students perform the actual composition during the writing activity on Fridays with a writing utensil and lined paper. According to Kathy Mills, a professor and expert in writing and literacy pedagogies, states in her book, Literacy Theories for the Digital Age, "The increasing availability and popularity of touch sensitive technologies, such as electric toys, smartphones, iPads, tablets and other mobile media for children's literacy learning has opened up unexamined changes to the role of haptics and sensorimotor elements in communication, education, and recreation" (160). Teachers should be encouraged to offer more digital avenues to display forms of literacies for students and could provide teachers with more engagement from students by providing agency and autonomy for an in-person or online composition class.

“According to Rose (2010), autonomy emerged as a significant feature in students' attitudes towards their language arts classes. Rose's study investigated students' critiques of their coursework and what they found to be most valuable and enjoyable. "Choice appears to be as important in motivating students to write as it is in motivating them to read. While writing to prompts is a necessary skill, many students would appreciate opportunities to respond to prompts that are less structured" (21). As a witness to this type of engagement, I would agree with the students from this study. Giving them a choice in what they write about can provide a more engaging opportunity for students to be in control of their own writing to a degree. Keeping an open ended question while offering life writing opportunities for students to write such as: "How are you?" may assist my students with their motivation to write on Fridays where there is that chance to write with less structured expectations.

How Stories Teach Us, edited by Amy E. Robillard and D. Shane Combs, supports my argument. This is compelling as one of my writing participants for this study is originally from 
South Korea. This is especially true if students come from a more diverse background as Lisya Seloni suggests in the chapter, "Moving Literacies: A Need to Tell Transnational Stories." “...transnational stories attached to foreign words could encourage openness to difference and patience to construct meaning and at some level willingness to connect with the felt sense of a foreign word/world" (98). I feel more supported by this text as my students began to open up more about sharing their thoughts, ideas, and their writing pieces once they knew it was a safe space to do so. The issue was that students would have reservations on being the first one to take the plunge and open up, showing that they were making themselves vulnerable. Keep in mind that, as the educator in the room, I often make myself the vulnerable one first, but even that doesn't always work. Oftentimes, it must be one student that has the courage to go first to show students that it's not as scary as what they may feel. Only then, after students have constructed some meaning and that same level of willingness to let themselves share, can I get my students to write and workshop at the level I wish them to.

Within the book, In the Middle, Nancie Atwell claims, "Here was an approach to teaching writing that allowed me to observe individuals in action, support them, and learn in my classroom. The first thing I learned was that freedom of choice does not undercut discipline or rigor" (12). Bret Turner, an elementary school teacher teaching first-graders stated in "Building Classroom Community Through Storytelling" that narrative has a direct impact on discipline in the classroom. "Classroom management and leadership — the systems and routines that become ritual, the community we build through shared agreements and explicit expectations and consequences, the agency given to kids - are discipline; or rather, they serve as more loving and supportive substitutes. Building a fun, safe, positive environment is the backbone of an elementary school classroom, but it's both an art and a science, a never-ending feedback loop of 
responding, tinkering, resetting, and rethinking, and sometimes even starting over from scratch" (Turner).

I am adamant that this would also apply to a middle level classroom as well. Especially if sharing narratives becomes part of a routine for the students. My students thrive on structure, so this expectation would additionally lead to easier classroom management because my middle level students know what to expect on specific days. If I allow students to choose which stories they want to recall and write about without telling them exactly what to write, students gain the opportunity to choose what is deemed "less risky" to share while still creating what I like to call a "controlled risk opportunity" where students will eventually share their compositions. Students may feel more comfortable on what they share with the caveat that they already know they get to choose what to compose and publish to the class. "Writing took its rightful place in the curriculum, not as an exercise, performance, or regurgitation, but as self-expression" (12).

A study was conducted focusing on the brain development within the first two decades of life for human subjects with information released in 2014. The study was to measure the developmental mismatch in structural brain maturation specifically during adolescents with twenty-four participants. It was concluded that the concept of risk taking can be affected during the time period as stated in the section of the study titled, Relating a Structural Mismatch to Brain Function and Behavior. "The absence of correlation in our sample might reflect the mismatch being associated with relatively increased risk taking within an individual as opposed to an absolute high level of risk-taking behavior. Thus, individuals may regard themselves more prone to risk taking in adolescence than they were during either childhood or adulthood, but still might not engage in 'high risk' activities typically assessed by standard measures" (Mill et al.). In the study it was mentioned that some students may increase their risk taking specifically from the 
ages of 13-18 years old, although some students may feel just the opposite and wish to take no risks during this time period with just as much vigor. This could offer an explanation which could lend a reason as to why more eighth graders may be more willing to share their written work over younger students like sixth and seventh graders. While teaching, I needed to realize that some students may be in different stages in their brain development where their risk taking may or may not be more likely.

Peter Lorain, a former middle school principal and President of the National Middle School Association, has written multiple articles with the focus being at the middle level and other educational issues. "They are creating an identity for themselves within and among a group. They are experimenting with different roles and personas -- but within the safety of the group. They are different, as the group is different. Though they are seeking their own identity, they will take few risks of being rejected from the group. As a result, they tend to conform to group mores such as dress, behavior, values, and activities" (Lorain). The fear of rejection caught my attention the most, and I agree that these are the main factors that contribute to a student's hesitation to speak, contribute, or try to be a part of a class discussion. I've been trying to think of how I can address this in the classroom.

With middle level students going through major shifts in physical and mental maturation, concerns about image and reputation can become increasingly stressful for students. This is further supported by the Association for Middle Level Education in This We Believe: Keys to Educating Young Adolescents. "Young people's desire for peer acceptance and the need to belong to particular social groups are often intense and sometimes lead to shifting allegiance from adults to peers" (AMLE 7). It is uncanny to watch students slowly switch their positive demeanors to different friend groups as they go through middle school. As witness to these shifts 
in middle level students' pursuits of acceptance, I can only encourage my students to be themselves in my classroom as well, hoping that they feel the acceptance that I know many of us spend a long time craving and not finding. "Caregivers and educators must remember that young adolescents hunger for informal interactions and conversations with caring adults" (7). I argue that allowing my students time to write reflectively about themselves and dedicating time for students to share allows this more informal interaction to take place.

When students feel moved to speak, they know that there is a physical space and time dedicated to them sharing whether they're ready to or not. The first major set up of this entire activity is letting students know that this opportunity is available to them. In addition to those components, I tried to make all of my students aware that I was open to hearing about them and invested in what they had to say. This addresses a couple questions that I find to be critical in my understanding of how my students function in my classroom. Are my students feeling seen? Do they feel heard? If the answer is yes to both of these simple yet important questions, then I anticipate students feeling as though they belong to our class. Overall, I argue that setting time aside specifically for allowing students to share their life writing proves to be a positive experience for their overall developmental and mental health despite the many transitions and hardships that come with being an adolescent.

There is the constant assumption that teachers already have the knowledge and skills that all students need to be taught according to Mirra in Educating for Empathy. "This model fails to consider young people as experts and maintains a power hierarchy in the classroom that prevents students' interest, passions, and capabilities from being taken seriously in academic learning" (80). My students are all smarter than me on at least one subject. I don't know much about archery, how an engine works, or the rules of fantasy football. My students can and do 
occasionally take the opportunity to educate me and the rest of the class when presented with these opportunities during our weekly life writing activity. Just because we're in a language arts classroom doesn't limit the learning experience to just the students. Some may claim that the time is being wasted, but I would shake my head. They're learning how to teach, becoming masters of their own crafts. Sharing experiences leads to their passions coming forward. The more I know about students, the more I can engage with them in the classroom. The writing exercise every Friday allows more personality in the classroom, while also giving students the opportunity to speak on topics that they're already knowledgeable about and comfortable with. This allows the transition to presentations to go smoother once students have already engaged in the informal practice of speaking in front of the class, some without being fully aware of what skill they had just practiced. It's one of my favorite forms of stealth learning taking place at the middle level.

The classroom experience becomes richer for both the teacher and students when work conducted in class is identified as valuable and academic by both parties. It is for this very reason that so many educators may get to the end of the year and feel the bittersweet tugs at the heartstrings because that fun, safe, and positive environment is coming to an end with that specific group of students. That environment is what allowed students to be themselves a little bit more in addition to the teacher. This opens up emotional and social opportunities for the class to engage with one another as well instead of only being academic. This makes for a more memorable year, developing inside jokes with classes, and feeling the bittersweet pang of disappointment that the year is going to eventually come to an end. Those memories make the learning more memorable for the student body which should dominate the education system as the goal is for students to become lifelong learners. If we [educators] can trigger that long term 
memory by creating this positive environment where students can freely workshop their writing with peers and the students can recall the skills from our lessons within the classes, I argue that all educators should be striving for this sense of belonging in their own classroom. It's difficult to be persuaded differently as I know that I wouldn't enjoy teaching without this sense of my students belonging in addition to myself also feeling like I have been welcomed into this group of middle school students.

With writing comes communication, and that is something I would like to focus on, the importance that this communication is also taking place in the classroom. With social media and digital literacy at the majority of the population's control, students have been able to practice using these different forms of media to send messages or converse through online platforms which allows users to interact and message through text, image, video, and audio within different chat channels. Jodi Shipka's Toward a Composition Made Whole introduces a different framework for students to utilize a hybrid of textual, aural, and visual forms of communication. “This, proponents claimed, would not only provide students with a stronger incentive for writing (or speaking, listening, reading, or thinking), but by testing "the communicative process as a dynamic whole," students would also learn to "appreciate language as a living, ever changing medium used by all kinds of people in all kinds of ways" (Dean 1959, 81-83) (Shipka 26). By combining the sharing of life writing, encouraging student engagement, and students understanding that language adapts to situations, could overall provide students with more intrinsic motivation to contribute to their academia.

To argue against Shipka, an article titled "Virtual Spaces" reminds us that students may not thrive on having complete autonomy, and may still rely on set structures, especially those dealing with technology. "Still other student comments suggested that the multitasking capability 
of the technology, including speaking, listening, writing, and viewing videos or PowerPoints, was often overwhelming" (13). Offering students too many ways to share their writing may be more intimidating than actually helping to take away the intimidation factor of sharing. I believe this could be addressed by offering students limited choices to choose from. This way students won't be overwhelmed by multi-modal possibilities, but they won't feel forced into one choice either, such as standing up in front of the class and telling their story.

I feel justified in my approach to this writing exercise done every Friday in my language arts classroom. With years of experience with this activity, I feel as though I can encourage other educators to dedicate time in class to give students the opportunity to perform life writing on a weekly basis with a specific amount of time for students to unpack what they wrote and have the opportunity to speak. I would suggest that this should always be offered but never forced on middle level students. In my experience as a middle level teacher, forcing a student to share something personal isn't a successful way to establish a positive rapport with that student.

The goal is to build a relationship rather than damage it. If a student feels uncomfortable or forced into a situation with their writing, it's going to impact that student negatively where classroom management will become more challenging because there is now opposition in the classroom rather than comradery between myself and my student. I want my students to feel moved and motivated to speak when they are ready. This makes later assignments such as speeches or writing workshops more comfortable as students get a chance to have voluntary practice in sharing their writing throughout the school year. As the writing activity is not worth a grade, it is not worth creating opposition with a student who does not wish to share. From what I've experienced, a student will share when they are ready even though it's not for a grade. The overall sense of belonging in a classroom can be identified as positive when students are allowed 
class time to share. This shows the students that what they have to say is valued as it takes up class time each week. This works best with a teacher who makes themselves part of this activity by modeling positive behaviors such as active listening, thinking critically about what the students shared, and responding with empathy.

From my experience, this writing activity works best with an educator that does not take on an authoritative teaching style. Through this process, those in the audience can mimic the modeled behavior to learn the appropriate way to respond to another student that has shared. Eventually, as I've seen by the third quarter in a typical school year, students may not need as much modeling as they've adopted proper etiquette on responding to life writing shared by peers. Once this classroom climate has been established, it may provide more academic opportunity for quieter or more reserved students to open up and feel comfortable sharing. The research further suggests that this writing activity can promote the sense of belonging where students that struggle from chronic absenteeism and depression may cope better in that type of classroom environment that promotes sharing in a constructive manner that is derived from the students' writing. This positive classroom climate will be seen as a safe space for students to share their thoughts, ideas, and memories in what they will consider to be a less risky environment for their social-emotional growth and development.

In this next section, I'll be discussing the questions that I had asked my former students to comment on. Students answered questions in two rounds. The first, focusing on their own personal views they've created on life writing and why. The second round of questions asked students to focus on how life writing had impacted them based off of the weekly writing activities that occurred within our classroom their eighth grade year. I will explain why I chose the methods that I did when coding the data provided in addition to discussing what students 
thought about their own personal experiences within the classroom. Within the findings, students wrote about what held the most value for them throughout the weekly writing and sharing activity. 


\section{CHAPTER III: METHODS \& METHODOLOGIES}

Aims

The juxtaposition between what the students remembered and what I had observed as their teacher would provide evidence if we both had experienced the shift in risk taking through sharing and writing. This was in an effort to answer the main question: In a classroom designed to promote students' sense of community, agency, and voice, how did students create an empathetic community through the experiences of shared composition? By reading through two rounds of questions for five of my former students' reflections, experiences, and emotions surrounding the life writing conducted in their eighth grade classroom, there should be multiple identifiers present in their writing that would show evidence that the case study participants had also noticed a shift in the classroom's social dynamics once students got accustomed to their weekly writing and sharing activity. The most valuable data for my research question would best come from the students who had been students within the same language arts classroom and went through the various experiences of writing, contributing, listening, and choosing to share their own writing their eighth grade school year. Based on the feedback provided by students would support whether or not the life writing activity is what made the connection to helping establish a classroom with empathetic members.

Qualitative research methods were going to be the focus of this study as the information obtained was non statistical data. The information obtained was categorized into identifiers or codes rather than charts or graphs as a means of measuring the data. As the intention for this study was seeking a reflection on different experiences of others, qualitative methods of data gathering would be used. The research question, being on life writing and the impact it had on students and helping them establish their voice in the classroom while fostering a sense of 
empathy for others, required an informed path of inquiry. Conducting a form of interview for students to reflect on, and observing what students had to say, would provide insight on what experiences students recalled about the life writing activity.

As this shift in student behavior had been observed over the span of five years in the classroom, the goal was to figure out if students had also identified this change and could explain what experiences they had that encouraged this shift in classroom dynamics involving their writing and sharing. According to Kathy Charmaz's chapter titled "Gathering Rich Data" within the text Constructing Grounded Theory, the seeking of valuable research data is described as, "combining ethnographic observations of numerous incidents with subsequent informal conversations with those present as a powerful data collection strategy," (23). This text was a major component with constructing methods on how to go about gathering qualitative data for this case study. Although the book focused heavily on interviews as a major strategy for gathering qualitative data, this was not the approach conducted for data gathering due to specific rules regarding students meeting teachers online at the time the study began in addition to the global pandemic. Regardless, the data gathered through student writing allowed students to have time to read questions and carefully consider what students wanted to report back on while reflecting on classroom experiences which had taken place a year to four years ago in their eighth grade language arts classroom depending on which grade level the case study participant was in. 


\section{Research Methods \& Explanation of Methods Chosen}

\section{Personal Observations}

There had been numerous occasions over the past few years where an empathetic tone of voice from my middle level students began to emerge during our Friday life writing activity. These observations initially occurred by accident and without intention of performing a study on the behavior shift of my middle school students. During the 2017-2018 school year, my third year of teaching, is when I began to critically observe the pattern of students shifting in their tone of voice, word choice, and willingness to share their writing with the class while also listening and responding to their peers. This trend continued on most Fridays during the school year, specifically with my eighth grade classes in the language arts classroom. As a lot of these observations were social between students, the constant comparative method of grounded theory was incorporated. The goal was to see if students picked up on these identifiers as well instead of only being observed by their instructor.

\section{Prescriptive Language Addressed}

It should be noted that some students may have had some grammatical errors present within their answers. If one answer posed the possibility of being difficult to comprehend due to a prescriptive language issue, the grammatical errors were corrected if offered in the findings to prevent confusion for the reader. The correction would not have taken away from the context of what the student was attempting to write as the study was not focused on the conventions of modern English. 


\section{Participants}

The school district I work at is interesting as we pull students from two small, rural towns, students who live in surrounding areas in the country on more rural routes, and in addition to pulling from Decatur, IL. This structure of indicating which students go to which school district creates a more diverse group that ends up in each classroom at my school district than the traditional rural makeup being nearly $100 \%$ white students. According to the Illinois Report Card 2019-2020, the racial/ethnic diversity made up of students at the district was, as of last year:

$82.7 \%$ White, $7.3 \%$ being two or more races, $4.5 \%$ Hispanic, 3.5\% Black, $1.7 \%$ Asian, and $0.3 \%$ being Pacific Islander reported. For the study, the student participants consisted of at least three of these categories. All participants for this case study were students that had participated and been a part of my classroom in their eighth grade year. These were students who would have been familiar with the writing activity done routinely on Fridays. Therefore, all students who participated in the study were between 14-17 years old when the study began. As of the 20202021 school year, all case study participants were either in their sophomore, junior, or senior level of high school during the data gathering process for the second set of questions.

The first student was Will. Will is a junior this year. Will describes himself as a scholar with a love of reading and going the extra mile on his work. Will was always critical and determined when it came to his work. Will never liked being wrong and was often looked at as the "smart kid" of his grade and rightfully so. Will constantly would impress his teachers with As.

The second student was McKenna. She is a senior this year. McKenna was oftentimes more reserved than her peers, but would speak her mind if someone said something she considered to be rude. McKenna would be quick to fix a mistake if she was informed of an error 
she made and always made a point to be kind. She was friendly to all of her classmates who would always return her kindness. McKenna was a student that was always willing to lend a hand to a friend in need.

Zachary is a sophomore who became my third participant. Zachary is what most people would describe as chatty. Zachary constantly is shifting his focus as he talks openly about social issues with others who may not be interested in the topic. Zachary is unapologetic when it comes to his identity. Being of the few students who openly identify as nom-binary and a member of the LGBTQ+ community, Zachary was always open to explaining himself while defending his arguments to those who are less open-minded due to him going to a school in a rural, more conservative community. Zachary is the reason more students have felt comfortable coming out to their friends at school about their sexuality while also being a part of this small community where there is more social pressure to keep those identities hidden. For this study and from wanting to reflect on his past, Zachary used a masculine pseudonym with the expectation that I would use masculine personal and possessive pronouns as that is what most of his peers identified him back in middle school.

Erin was always thoughtful, quiet, but had a lot of social pressure to do well in school as they were the child of the middle school principal. Part of what made Erin's personality was the knowledge that they were adopted from South Korea when they were a baby. That heritage has stayed with them to where they often identify themselves by their birth name in addition to their adopted name. Erin was always perceptive and eager to do homework even when they didn't need to do it. In addition to being one of the academic leaders of their class, Erin also had a high interest in theatre and musicals and was always enthusiastic about being in choir class and continued to have these passions well into high school. 
John was the final member to join the study. John, now a senior, had a rocky start in eighth grade when he moved here. Quickly he tried to establish himself as "the tough guy," but slowly let his personality shine after he realized he didn't need to defend himself. John was constantly talking about his street smarts when it came in handy with a certain disdain for academia. Regardless, John always put forth his best effort when it came to his work, and slowly opened up more as the school year went on into his eighth grade year.

The best way of learning what had occurred to these students was to ask them to reflect on their experiences and look at the feedback students provided. These case study participants were high school students selected from a pool of former students that had been participants in our language arts classroom when they were in eighth grade. These were students who were considered to be reliable and possessed the ability to provide me with writing that encompassed their full range of thoughts and emotions when reflecting back to our life writing activities during their middle school experience. Previously, there had been feedback from parents who saw value in the study being conducted as they thought the act of being a participant would contribute to students seeing that education goes beyond the year they graduate high school. These were parents who were also ready to give consent for their high school child to be a part of the study. Additionally, I specifically wanted to ask for participants who could be a part of this study while maintaining their grades, extracurricular, and other responsibilities without feeling overwhelmed. This was due to the expectation that I was asking students to consider questions with multiple layers to consider and reflect back on that could potentially involve quite a bit of writing. The subjects were kept to five students that ranged in grade levels as well as gender. This was to serve the best approach for the study as there would be a substantial amount of writing to process with locating patterns and codes in the data provided. The participants of this 
study were meant to serve a variety of opinions, thoughts, ideas, and an array of stories, memories, and other reflections. Furthermore, these students participating in the story had either consistently written at grade level with paragraphs that ranged from five to seven sentences or the student had shown exponential growth to meet this standard of quality writing by this point in high school. This was important as the writing needed to be long enough to fully contain the main ideas and concepts students were asked to write about. Limited writing would have been presented with too little data to draw conclusions from. Therefore, the high school English teachers at the district had provided their professional opinion on whether their student could handle the workload while also being a part of the study.

As the case study group, high school students, formerly my middle school students, were under the age of eighteen, I needed to obtain multiple forms of consent to appease IRB to conduct this study. I received consent forms from former students who were willing to be a part of the study along with parents'/guardians' consent as the case study data was coming from underage individuals. I was additionally granted permission from my administrator at our district to conduct this study on my former students who were now at the middle level as long as the students were willing and I had obtained consent from a parent/guardian of any students participating in the study. I was able to obtain IRB approval and move forward with data gathering. 


\section{Participant Questions}

The goal was to get a general idea of how students reflected back on their experience with life writing. There ended up being two separate data gathering events where students wrote responses and submitted their answers to open ended questions where students would freewrite as their responses. The second set of questions was to change the focus from the activity of life writing to focusing on themselves and reflecting on any changes identified in the class.

The first questionnaire had three focus questions. These questions were developed to ask students about their own views and opinions on life writing. I wanted to know what my former students thought about how they thought we used life writing in the classroom to see if it matched what I had thought as their teacher. The first question, being: What has been your experience with life writing? There was anticipation for responses to be focused on either an emotion or a narrative to explain why a student had these feelings in connection to the life writing activity that they had done weekly in eighth grade. The second question asked: Why do we use life writing in the classroom? The answers for this question were interesting as some students focused on who we referred to as all involving their classmates, themselves, and me as their instructor. According to some of the responses, it seemed that students didn't know the genuine reason - measuring sentence fluency to see which students qualified for R.T.I. with this universal screener activity designed for writing. This was good as I had no longer been using this activity for that intended purpose. Although the universal screener information was still valuable, and occasionally used by R.T.I. or the SPED team, all students wrote about getting better at communicating with others, specifically classmates. The comments about communication were discussing both spoken and written communication in responses. The third and final question for the first round of questions to be gathered asked: What kind of community can be built through 
writing and discussing together as a group? Letting students speak, giving students an opportunity to be heard, and letting them know that time was dedicated to them doing this activity was brought up. While there was some initial confusion on what "community" meant, students responded with the classroom dynamics and their observation of changes that took place the more the writing activity continued on Fridays.

A second set of questions was needed from the same students as I wanted to see an expansion of the students' reflection on their eighth grade writing class. The second round of questions were developed as an extension of the primary questions. It was important that students discuss their experiences when the weekly writing and sharing activity occurred in class. I wanted to know what my students found valuable about that time spent together by specific examples that they remembered. This is what led to students writing about a memory and sharing their own stories as part of the data. The goal here was to refine and develop those initial findings as is supported by the constant comparative method as grounded theory methods encourage building and developing data based on earlier analyses.

Once the data emerged from the first round that focused on students' opinions and ideas on the weekly life writing, there were gaps to fill in surrounding a focus on students reflecting on themselves in connection to the writing activity rather than on the writing activity itself. The goal was to maintain the same participants as the secondary questions were designed as an extension for the initial project. This would also allow students to discuss their own observations about the writing activities' influence in the class instead of focusing solely on the writing activity similar to the first set of questions. This also allowed the maintaining of IRB approval as the questions were on the same basis as the previous with the same amount of students. The second set of data gathering questions only had two questions for students to answer, but encouraged a range of 
ideas for students to consider and reflect upon. The first question in the second round of data gathering asked: Can you describe a past experience when you've been asked to share your writing with a class? Which class was this? What grade were you in? How were you asked to share? Did you feel comfortable with this experience? How did that experience make you feel? Did it go well or poorly? Please give as much detail as possible. If you have multiple experiences you wish to write about, please do.

The second question asked: Describe how you believe students' sharing their writing affected the classroom community. Were any classroom relationships affected by this sharing of writing about life experiences? Do you recall any shifting in positive/negative relationships (significant others, friendships, peer relationships) as more students shared their writing in the classroom setting?

These two questions students were given were designed to have students reflect specifically on students' comfort level with sharing their writing in the classroom in front of the teacher and peers and considering if that situation was remembered as valuable to their time in class or not. The second question specifically focused on seeing what students remember about sharing or hearing other students share their writing. Students were expected to discuss shifts identified in relationships between peers or friendships only from the time spent discussing writing in a language arts classroom setting. 


\section{Data Gathering}

The first round of data gathering took place in the Fall of 2019 during which time I was taking a Research Methods course with Dr. Broad where I initially had the idea for this study. Students had a week to respond to the questions. The second round of data took place a year later, Fall of 2020. For a more in depth writing opportunity, students had two and a half weeks to complete the second round of writing questions. The questionnaire was made using Qualtrics in order to get anonymous responses from the students that had completed the survey. One-to-one interviews were not allowed at the time within the school district. Therefore, the questionnaire served as the primary vehicle for data gathering purposes. I decided to continue to obtain data in a similar fashion to gathering the data for the second set of questions. Students were sent the questions through their school email and given a month to read, consider, and respond to the questions. Every participant took time to look over the questions early, heavily consider what to answer for each one, and then complete the heavy writing task being asked of them in their reflections.

All students provided an interesting look into each of their separate lives in how they remembered the class while recalling, and reporting out on what stood out to each of them from the class. With the focus on the Friday "Power Writing" activity, students specifically reflected on what they remembered and how their way of thinking changed that year and since then. Each set of questions were copied from an original so that students would have their own separate set when sent back without knowing who else was participating in the study. Each student participant's writings were valuable in their contributions to pointing out moments that were meaningful to them when it came to sharing their life writing and listening to others. 
While some students continued with their pseudonym from the first set of questions, others asked to change theirs, which was permitted. To prevent confusion for readers of the data, I've adjusted the pseudonyms to match the second set of questions and answers mentioned in the findings chapter.

\section{Research Gathering Limitations}

This widespread pandemic prompted all of the data to be submitted online through a questionnaire, similar to the first round of questions while data gathering. In-person interviews were not allowed during the school district at this time and was against better judgement for all involved in the case study. I believe the findings would have been more extensive had students had the opportunity to utilize a different method of delivery for their questionnaires. By meeting face-to-face or using online meets to conduct an interview, there may have been more information with the openness of having students answer questions verbally while being recorded. I could have asked students to explain, go in depth, or point out some more interesting things that students could have said. This is what could have led to different codes through memories, associations, or reflections students would have made through discussion via interview over a written questionnaire. All of this prompts the possible continuation of this study beyond the data gathered for this thesis alone. At the time of data gathering, the goal would be to be in person with recorded interviews along with a larger group of case study participants. 


\section{Data Analysis}

While using grounded theory methods, I had become familiar with codes used in qualitative data. Therefore, when looking through the answers students provided me with, I attempted to find similarities and themes between multiple answers between all students as a means of developing my own codes for this study.

The first round of questions presented data that focused on experiences these five students had. The reflective answers to the questions were the only materials used to draw conclusions from for this study. The codes that were discovered were: being heard as an individual, an emotionally charged response, or reflection on the positive aspect of the overall experience. Before analyzing the data, the goal was to look into the significance of why the writing exercise wasn't seen as a worthwhile experience. Overall this was reflecting on a previous class, so it was interesting to see the shift of the students' perspective take place over the course of their written response to the survey. One of the first and most striking codes that emerged were narratives of what students remembered. These narratives were emotionally connected to the students as they had to do with something significant going on in their lives including physical illness, mental health issues, and moments of students feeling vulnerable. Students recalling different stories shared in class were those where the case study participants felt especially moved by either something that they had written and shared or heard from another student. The shifts that students went through emotionally afterward were specifically targeted within the second round of data gathering. This is where the first evidence of empathy being fostered through life writing and sharing emerged. This prompted more research on empathy and at what levels could middle school students engage in empathetic communication. When students had written about sharing and being heard in the classroom, by having a platform where 
they get to share writing, allowed the second set of questions to further target the pressures of writing and sharing.

The second round of questions presented data that focused more on having students reflect on themselves and others in the class rather than the writing activity. The goal was to see if students identified a connection between the weekly writing activity and themselves as individuals. Asking students to think about others in the class assisted with students thinking about how they had changed from middle school as they got into high school and how they made assumptions about their peers. Based on students recalling the shared stories from their life writing from the first set of questions evolved into students writing about the changes that they felt after hearing, sharing, or learning about another's experience. This is where the shift in classroom dynamics began to make themselves more apparent as students discussed changes that they had made either in how they thought about a different person or how they had changed an assumption about peers who were different from them. This shift is what developed into students moving away from egocentric ideals where students were more concerned about themselves over a peer's feelings or emotional needs. It appeared that the emotional investment is what drove middle school students to feel encouraged and more comfortable in sharing their writing with the class regardless of the social pressures that were still established. This is also seen when multiple students mentioned that they had felt more comfortable with sharing life writing on Fridays after the routine had been established and other peers had already shared their writing first. There was an instance of a student participant mentioning the potential therapeutic value of sharing life writing in the classroom, yet the code was dismissed as data was limited.

After analyzing the two sets of data, it assisted with identifying what needed to take place in order for students to begin this shift away from egocentricity. To have a more empathetic 
group of middle school students in the same classroom, those who could write and share could develop a rich and diverse classroom where students felt they had control over their work, could take ownership of their writing, and used the social pressures of sharing writing to their advantage. The data provided evidence of what needed to occur in order for students to understand the value of their own writing. Case study participants all pointed out that designating time for the activity, knowing expectations, and establishing trust through rapport building seemed to have been the reason for students to fully emerge themselves into the weekly writing activity where these shifts in the classroom could occur. 


\section{CHAPTER IV: FINDINGS}

\section{Data Gathering}

This first round of data gathering for this study focused on life writing and students' perceptions of the weekly writing activity taking place in their eighth grade year. A lot of responses for this included anecdotal writing about students' reflections in the classroom. Some responses contained stories that were happy and animated while others had more serious writing to share. Students recalled various experiences other individuals opened up about in their reflective writing.

The second round of data gathering for this case study focused on the same group of students, but with questions that expanded the focus to include student writing on perceptions and shifts in thinking about themselves and their peers when it came to sharing writing. Some of the largest takeaways came from students' perceptions of the shared writing experience and whether or not they found value in that time provided in class. There was a trend in student responses discussing the perception of writing as a shared experience. Another commonality between students' reflections discussed a shift in their own perception of their peers and the dynamics of the class overall. The final reflection that was shared in all responses had to do with students commenting on their own personal growth.

The questions then extended into asking students about their perceptions about why students thought life writing is used in the classroom. Responses centered around life writing benefiting students' ability to write better or write more quickly, but a few students pointed out connections being made between classmates. The final question in the first round of data gathering asked students to comment on any relationship building they noticed with their classmates after writing and sharing as a group. There were promising comments from students 
about the benefits of having a designated time in class for this writing activity, letting students be heard, and speaking if students felt the desire to.

While looking through all of the data, there was an acceptance about the expected weekly routine of students grabbing their writing folders and notebooks on Fridays and preparing for our weekly writing session. It became habitual for students to expect this activity once a week. There were a few patterns that stood out when all student responses were compared. Some of my previous students commented on personal experiences that carried a lot of emotionally charged stories while others talked about general feelings on the activity, be it an opportunity to be expressive or identified as a risky experience with reasons why. In addition, students showed a general outpouring of support in favor of life writing in a middle school language arts class with few poor perceptions. The other major component that came up, which was unexpected, was students discussing their ability to contribute to the class because of what they chose to write about. Student voice and being heard was brought up as well. Students seemed to reflect on the ability to feel like they have autonomy, choice, and a general sense of being in control and having their own agency from their own writing from class.

\section{Experiences of Empathy: Personal Experiences \& Emotionally Charged Stories}

The reactions and responses reflecting on the students' eighth grade year of life writing in the classroom focused on experiences students recalled. According to the responses, students seemed to enjoy the routine and knew that they were going to be able to write about something important to them and then get to talk about it if they wanted. John, a senior, wrote, "As I grew older, the topics seemed to get more interesting. The topics were relevant questions that were thought provoking and necessary." As the student got more comfortable with writing, they began to shift their way of thinking from believing the activity to be a waste of their time to being 
engaged with the writing and caring for what they were creating in their paragraphs. This was calling back to the sentence fluency exercise being introduced back in fifth grade. McKenna, a junior, had written, "My experience with life writing was fun. It was always a great end to my week, I always looked forward to writing. One thing I liked the most was the "How are you?" prompt. It was nice to try to evaluate and summarize my week or even just that day. Hearing others' stories was also enjoyable, whether they were comedic or some bad news." In my classroom, the empathy that came from questions that the student had okayed allowed students to become so much more aware that the world doesn't revolve around them, and that other people, including teachers, are all dealing with something. Students that would normally never speak to this student would ask for an update, and they would have a quiet and quick conversation as we were setting up on our writing day. Students seemed to enjoy the storytelling element of the class on Fridays, and knowing that others were going to share helped to encourage more students to contribute to the class discussion. McKenna also included, "Life writing was a very relaxing form of writing because it allows us to share our feelings through writing it down and talking about our problems or just something fun we did."

There were rare moments where a student opened up about deeply personal situations in their writing and voluntarily shared with the class, as Zachary, a sophomore, states here:

"One day I was really struggling with my anxiety and depression. The teacher already knew about it, but I was having a bad day because I found out that my mom had thyroid cancer. (She's fine now.) I didn't tell anybody except my girlfriend, [name redacted], and I was gonna lie when Ms. Reynolds asked us how we were for our first writing question. We normally talk about our lives and sometimes I don't like doing that, but I wrote about my mom. I don't talk with her very often and there's some stuff that happened where I can't see her anymore, but I still 
felt a lot of emotions about her diagnosis. I was sad that she was sick and angry that there wasn't anything I could do. After we got done writing, Ms. Reynolds always asks if anyone wants to share. I kind of raised my hand without thinking, and it just all came out. I don't think I would have normally shared all of that information, but it did make me feel a lot better once I told Ms. Reynolds and everyone about it. I wouldn't consider a lot of the people in my class friends, but I got a lot of support, so that was good." It was this experience where multiple observations were made when a handful of students had reached out to Zachary to show support before, during, and after class after that. These students that had made these remarks or pulled Zachary off to the side hadn't been members of his immediate friend group.

Zachary had felt the need to open up and he took the opportunity even though it may have been considered as a high risk situation from a social standpoint. Zachary knew sharing this was going to make him feel vulnerable, but he shared his writing with the class anyway. Students would share similar stories that seemed to come out of nowhere as students hadn't opened up to many people about certain hardships in their lives, which is not always anticipated. Personal stories would never be forced out of a student or encouraged without the student making the active choice to raise their hand and share what they wrote about. However, occasionally, when stories like this would occur, those in the room were occasionally caught off guard from the experiences the students chose to share. Sometimes they were happy, silly stories. Other days, the life writing required an active listening and empathetic ear from the audience. 


\section{Mutual Aid and Support - Not the Only One Struggling}

So many students carry burdens with them throughout the day that others are not aware of, especially with so many students coming from different economic and demographic backgrounds which make up diverse living situations for students. Because the opportunity to express was available and the classroom culture of acceptance had been established, students like Zachary were able to share profound and significant writing with the class. The friends, acquaintances, and peers that he didn't typically seem to care for, showed sympathy during this time, and it was a big moment for the culture of that specific class period of eighth grade language arts that year. Erin, a sophomore, wrote, "Sometimes it was just nice to know that you weren't the only one struggling." There were days that something was clearly on the minds of the students. Everyone would be on edge or be distracted, and it would get in the way of the lesson. Oftentimes, life writing and connecting the event to one another would be the best way to handle things in the classroom if there had been some drama or hurt feelings throughout the day. Erin added, "When you life write, you pour out emotions that you have been keeping all bottled up. So when you share these emotions and others share theirs this helps form deeper connections with the people around you. You could severely despise another person, but if you know where they came from and who they really are you could sympathize with them more."

Life writing on Fridays gave middle school students the time to unpack some of those bottled up emotions. Sometimes students and educators need the opportunity to have that catharsis, and get something out that has been bothering them. This is supported by another student, John, who mentioned, "When my class was angry about something, we vented it through Power Writing time, making ourselves feel better and we were a lot calmer usually," while McKenna also wrote, "She [Miss Reynolds] let us talk to her about the ups and downs." Life 
writing is in no way a substitute for mental health medicine, but the communication, discussion, and writing has seemed to hold therapeutic value for students who were struggling mentally as a lot of students claimed that their mental struggles were often ignored or not taken seriously. The best example comes from another personal anecdote that Erin wrote about.

"Being able to share helped a lot of people in my grade. So many of my friends and classmates opened up about bad things that have happened to them. Like abuse or neglect. We had someone open up about drug use too. We were only eighth graders too, and that makes me sad. I was able to talk about the suicide hotline and people who can become advocates for students who don't feel like they have anybody. I remember Ms. Reynolds let me put the numbers for awareness up on the board. I was crying and she was crying too after we all talked to each other. I loved that class because we cared about each other in that class. That's changed a lot in high school." Will, a junior, wrote about hearing some of these stories in class from other students when he states, "The kind of community that's built through life writing is strong and compassionate. Hearing about other's lives can make the students feel they know each other more. From what I saw as I taught, some students shared some deep parts of their lives with the class, which meant that they had lots of trust from us and they could rely on us to listen. Every person needs to have an outlet to release their emotions, and life writing could definitely become that outlet."

\section{Being Heard - Opening Students Up to Something New}

Many students in our school district began performing this writing activity called 'Power Writing' in fifth grade, and they had some responses that weren't in support of my former students identifying themselves as writers. Erin wrote, "I first started life writing in fifth grade, and I hated it. We were never given interesting topics to write about, and were not given the 
option to write about something we wanted to." It seems that similar to adults, our students also value their time and want justification and why they are being asked to do something in the classroom. Another student, Zachary, wrote, "We would write and then immediately move on to the next topic. We never talked about what we wrote and it was a huge waste of everyone's time." When students were not being asked something that they could connect to, they wanted to rebel against the challenge being asked. Furthermore, not being able to discuss and decompress everything that the student just thought about in order to write was then asked to be put off to the side to perform another writing activity. Students wanted to share and were not allowed to talk about the experience they had just written about. Students wanted their writing to matter and their voices to be heard. Actions needed justification and allowing students to share and expand on their writing could accommodate that desire.

Students were always aware that they were never forced to raise their hands and tell the class about what they wrote. They were always encouraged to share if they felt the need to, but were also encouraged to believe that writing can be deeply personal, and that writing out frustrations is just as valuable as other forms of writing. Sometimes the biggest thing students can do for themselves is to become aware that they are still writing to themselves, even if they don't share with the class. A student is still their own audience member when writing. This can get them more comfortable with the idea of writing and self-identifying as a writer.

Another student, Will, wrote, "While life writing you answer certain questions that challenge you. You answer the questions that really force you to dive into yourself." Deciding to share that information was completely up to the student at any given point and time. Knowing that others would share helped other students who were typically much quieter, raise their hand, and make connections to the rest of the class. Zachary added, "Some people in my class were 
antisocial, but by the end of the year, they would participate in Power Writing opening them up to new things. We get the chance to really talk and say how we feel about things in that class when students are normally told to be quiet in school."

This was beneficial as the sharing time allowed students who would typically never get to talk to this other student, make a connection to them because of their previous connection to another student. Erin continued to write, "We use life writing in the classroom by providing an outlet for kids who don't have one. They can write about anything that's going on in their lives, basically venting to the notebook, but they don't have to share it. For some students, this can help them tremendously, just by getting their thoughts down somewhere.” The further into the year it got, the more students would typically open up. By the beginning of fourth quarter, it became more of a writing and social event rather than an individual one. Students will raise their hands to speak because they know they have an audience that cares and feel as though what they have to say has value, and that's because it does. Will added that, "We also use life writing in the classroom to help us feel we can talk to Ms. Reynolds when we need someone to talk to. Like, she actually cares about what we have to say. I feel like we all had a voice in that class. I needed that as an eighth grader when I hated school, but I didn't hate that class. I learned and had fun in that class."

\section{Pressure to Share Writing in the Classroom - "I Like to Hear Others Talk First"}

One of the main concerns going into this weekly writing was being clear that this writing activity, involving life writing and discussing, did not force students or pressure students into sharing personal stories without their consent. One of the goals of this new set of questions aimed to ask students to provide feedback on if they had ever felt this form of pressure during the writing activity themselves. It was important to get a clear answer from students if they had felt 
this way in any of their writing courses. It was for that purpose that students were asked to reflect on whether or not an instructor had put students into this difficult position in connection to their writing class. If so, it was predicted that students would share experiences that made them feel uncomfortable if done so against their will. If not, it was predicted that students would have been more open to the idea of sharing if it was encouraged, but never forced. An interesting note was that none of the participants in this case study claimed that they had ever been forced to share personal writing. This was encouraging, but there was the need to unpack how students felt about sharing their writing in general, even if it was voluntary.

One of the students, Will, reflected on other written assignments from his eighth grade year while discussing a composition assignment. "All the papers were kept anonymous so no one felt embarrassed or personally attacked when we gave feedback." This writing exercise was to further provide opportunity for students to practice providing feedback openly in addition to receiving compliments, comments, and other critiques on their writing. With a certain amount of anonymity, students would be aware that only the content of the writing was being judged over feeling judged personally by another individual in class. This helped take some of the social pressure off of students who would deem this writing as a "high risk" experience from a social perspective that could potentially prevent students from wanting to share their writing or taking the risk to share if they felt the desire to.

Erin added, "I've not always been asked to share my writing in all of my classes, but I know that I shared more in seventh and eighth grade for my language arts class." It was a point of interest to learn that Erin claimed to have shared more during middle school than in high school. I was curious as to whether the dynamics of the class had something to do with that amount of sharing writing changing for Erin. Knowing that this student was more reserved and 
quiet in middle school, it also made sense when they added, "Normally I like to listen to other people talk first, but I will volunteer occasionally.” Erin also commented on being encouraged but not forced into sharing by including the comment, "I never felt pressured in a bad way to open up about my writing, but the teacher would always encourage us to share if we felt like it. I wouldn't say I ever felt forced into it." Zachary claimed to not have a good memory, but recalled that, "I do not remember having to share any significant form of writing with a class before." McKenna claimed that she had been asked to share writing before but was never forced into it. "I feel like it always went well for me, but if there was a day that was bad, I never was pressured to talk about it, so that made it better too." John's answer was similar to McKenna's. "I have been asked to share answers before but sometimes I'll say, 'I don't know,' if I did not raise my hand," John wrote. "I have shared more writing in high school than before, but I did share writing my eighth grade year in English [class]."

Regardless of the participants in the study feeling as though they were never pressured, multiple students commented that they have been called on to share in the past without raising their hand. Even though those in this study claimed that they didn't feel forced, the act of being called on without a hand in the air does provide a certain amount of social pressure to provide an answer and should be kept in mind as an educator. If the case study participant group was larger, it is anticipated that some students may have written about being called on without raising their hand as being perceived as an experience deemed too risky involving social or academic pressure to share something personal with the class. 


\section{Willingness to Share Life Writing - Being on the Same Level as You}

Another commonality between all participants included the students reflecting on their personal experience that involves sharing writing in the classroom. The goal was to see if students found value in the writing activity associated with sharing. Realizing that there may be factors that I was unaware of as the teacher, the answers were going to potentially be able to let me know what was going through students' minds that determined if the perceptions of their shared writing experience was going to be remembered as having mattered to them or not. Will's reflection was positive, stating, "I thought this experience was beneficial because getting feedback from your peers is very helpful because they are on about the same level as you." When prompted on what Will meant about what "about the same level" meant, he clarified that he meant grade level and how a classmate could understand another middle school student's problem. This would have been because students were around the same age and may have been going through similar situations which made any feedback valuable.

Some of these classes seemed to contain more friend groups which could have also affected how quickly students would have been willing to share any life writing in class. Occasionally, other students would have been a part of another student's story from being in a similar friend group. Sometimes this would cause multiple students to want to explain the same story that was being shared. Even though students would be ambiguous in who else would have been a part of an experience, this was overwhelmingly seen as valuable class time spent with the class when this would occur that Erin expands on specifically. "I normally wouldn't have shared it, but it made me feel good because everyone was laughing." With other students encouraging the story or being eager to hear what another student has to say proved to be more encouraging for some writers. Erin also wrote, "Because I felt more comfortable, I shared more of my writing 
in the class." Having classes where some students had already established friendships or some form of bond was identified as causing students to open up more quickly when it comes to sharing life writing. It will most likely take a little bit longer if students are acquaintances.

Zachary viewed the experience as "good when people shared their writing." At the beginning of the school year, the stagnation in conversation, sharing, and writing would prevent a flow in the classroom if students chose not to share. When students would begin sharing, the class would run more smoothly when students were willing to question, reference their writing, and actively listen to others. While thinking about the entire class, he reflected, "I think the writing only made the classroom setting feel more comfortable and closer." Zachary included a personal shift that he experienced throughout the school year when we shared life writing every Friday. "From my perspective, sharing writing only made me feel closer to my fellow classmates." This was a surprising reflection to discover as this student oftentimes would share how they felt different, other, and ostracized from the rest of the class. Gradually, this individual ended up being one of my students who went from not sharing, to sharing the most often as the school year progressed.

McKenna shared a similar thought when thinking about the experience as a class in contrast to her own personal experience with sharing. "Thinking back, I enjoyed hearing other people talk because I love stories...we were honest with each other when we spoke, but we were never mean to each other." What McKenna mentioned was always a major point to listen carefully for from the teacher's perspective. Occasionally, students would open up in their honesty and, when a student would respond to the shared material, the social risk was present. Comments at that point could easily determine if a student would open up again or not based on how well their sharing experience went the first time they decided to take that risk. As McKenna 
mentions honesty, it had to be modeled by the teacher and monitored as some students claiming "an honest remark" could easily be unintentionally hurtful or careless. As happy as I was to discover that a student reflected that there was never the intent to be mean to others, comments taken out of context or not carefully constructed before responding could be potentially damaging to this writing experience. When comments like this would occur, it was important that the teacher ask the students to clarify and politely remind students of how to correctly respond to another student's shared experience.

These answers would serve as a guide if this activity was seen as valuable or identified as useful. If comments proved to show that students thought of the activity as a waste of time or without much meaning, it would alter previous perceptions from a teaching standpoint. The value of this activity would have dropped significantly had students not been able to find value in the activity on their own. Overall, John sums up what students thought of this shared writing experience. "It was okay once I knew everyone. I liked the class and it went well." When writing specifically about the writing activity, John wrote. "It was still fun to share."

\section{Shift in Classroom Dynamics - Identifying Each Other's Passions}

Another interesting pattern that came up in the data had to do with student perceptions focusing on the class rather than themselves. It was anticipated that the answers provided would be centered around the student participants, so the data that came from observations about the class that didn't involve the participant was unexpected but welcome. A few of the comments pointed out how personal thoughts are sometimes best left unsaid, but addresses an important shift that took place as students made judgment calls about the activity, themselves, and the rest of the group in silence. Will states, “I think the class' writing helped everyone understand each other to a higher degree." This was reinforcement for the continuation of a reflection on the 
activity, but then Will went deeper by adding the hidden thought, "For example, someone in one of my classes wrote about cars and the working of them. I actually thought this student was the worst in the class, but their writing about cars showed that they really had a passion for working on cars."

Will wouldn't have typically been the student to even comprehend saying this out loud to another individual, but the honesty presented in the writing allowed the connection of this shared writing experience to change how Will thought about this other student in the class for the better. Will concluded with a final thought. "These writing exercises helped me shift my view of those students that I thought were just unintelligent to be the viewpoint that they have other skills/ interests that can serve them in life if they put forth the effort." The fact that Will, now a senior, was able to think back and realize that a change occurred for him back in eighth grade that shifted how he judged others demonstrates value in this shared writing experience. If students can judge less harshly the more they learn about other individuals, the personal growth seen from this writing and sharing activity would be predicted to be more encouraged in different classrooms.

Erin discussed the activity objectively for their class as well. "The writing only made us [the class] connect to each other and then we would all want to share a similar story." Erin specifically discussed the combination of writing being used as a springboard for stories to develop and connect between students. This was followed by the reflection, "Looking back, that is what probably made us closer as a whole group. It's hard for me to say because I had a lot of friends in that class, but even the people who I wasn't close to would connect with others." Erin brought up the observation mentioned earlier about how classes that had friend groups within them would open up more quickly with the shared writing activity as valuable connections had 
already been established previously with those social connections. However, it was still observed that the students this participant didn't consider themselves close to also connected with others in the class through the weekly writing activity.

Erin expanded on the comment by explaining why these connections were taking place in connection to what was going on in the eighth grade language arts classroom. "I think our class began to respect each other more just because we learned about some of the things that people were going through." Erin concluded with a reflection on how the class was eager to get out of middle school while still appreciating something deemed memorable from the class. "We were happy to go to high school but sad to leave the memories from Power Writing every week. I don't think the class would have been the same without it."

Zachary, a junior, also discussed the shifts perceived in the classroom when he wrote, "I think the entire class sharing their writing and feelings on a topic did make the community in that class feel very open and generally have positive vibes." Again, there is a reference to writing or sharing being a forced activity that Zachary addresses. "Having everyone share writing sounds like a forced ice-breaker exercise but it actually worked out very well.” After Zachary had shown vulnerability by openly sharing his concerns about his mother having cancer, Zachary became a strong supporter of all activities done in the classroom. "The people of the class made the class very accepting and kind, and sharing writing was very positive." This spins previous observations on its head as this student claims that it's the people who make the activity a valuable experience rather than the writing and sharing as previously stated by other former student participants in this study.

McKenna, a junior, discussed writing and sharing generally, not in connection to the one specific instance of the weekly writing activity. "I feel that the writing and opportunities to share 
that writing would make people talk more and open up about more personal perspectives from their lives." Keeping in mind that this should never be a forced activity, students should also feel that they are heard if they choose to open up about something that may make other students uncomfortable, such as in Zachary's case when he opened up about a severe illness in his immediate family. McKenna further discusses the value identified in the writing activity that would take place every week. "It was good for us to talk about it and get that out, otherwise the story would have felt kind of meaningless when it wasn't." Allowing students to unpack what they wanted to share, through questions, comments, or providing other students the opportunity to reach out with supportive statements can also be beneficial. Allowing students to feel that they had time to share and be heard is significant, as stated by McKenna. When a student opens up, those in the classroom need to become active listeners so that the other student, who took a chance by opening up, doesn't feel shut down.

McKenna further supported her statement by connecting the writing opportunities and the importance of dedicating time to share and respond to those writing opportunities to how these caused the shift in her perception of herself with her peers in that class. "I think that writing is what had us open up about ourselves, and being able to speak if we wanted or needed was what caused us to feel closer to each other because we were communicating it...it was easier the more people opened up.”

Although John included himself in the observation about others as well, his writing echoed back to how he was encouraged to share and write more after observing peers opening up more and engaging in the writing and sharing exercise as other participants had mentioned as well. "I think that's when I started to try harder in her class but the rest of the class also wrote and opened up and that made it easier for me when someone else did it first." By allowing 
students to feel comfortable at their own pace, letting students see other peers take the chance to share can gradually allow those uncomfortable students to gain the confidence to be an engaged participant that builds this culture of acceptance, kindness, and willingness to share with others.

\section{Moving Away from Egocentricity: Communal Awareness and Action}

Now that all of the case study participants are now students in high school, thinking back brought up a few responses where students' commented on how they had changed since attending middle school. A few of the students brought up how they had matured or mentioned realizations that they may not have made back in middle school. John brought up how he was new in eighth grade and that had prevented him from joining in as much. "I eventually spoke more but I know I did not write as much as I probably should have.” Will furthered his understanding of himself and others when he commented on how he came about realizing that academia didn't come natural for everyone when he wrote, "This allowed me to realize that not everyone in language arts class (and school in general) is gifted in that area of life." Will had become more aware of those around him which ended up changing how he perceived the other students in the classroom.

Erin brought up gaining confidence over the course of the school year while also selfreflecting what kind of student they were looked at as: the "quiet kid who gets good grades." One of the most significant reflections of Erin involved a change in how they’ve grown as an individual when they wrote, "Some things [comments shared] were really personal and I felt bad for them [classmates]. I guess the writing did change how I would have tolerated other students. We had some loud people [constantly providing a distraction] in class, and I was more patient with them after I found out what they've gone through, which I can't imagine.” Erin remained thoughtful and considerate to all students throughout this reflection, even concluding with, "I 
don't think I'm allowed to write about their [classmates] experiences, but it made me realize how lucky I am to have been adopted into a family that takes care of me."

Zachary also reflected on how he learned about people other than himself, despite labeling himself as a "very loud and talkative student" to focusing on others. He further commented on how he typically views people as being "2-dimensional" in classes when you don't know someone and only have a surface level of understanding. This thought shifted with the comment about the life writing and sharing activity done at the end of each week in class when he wrote, "The more people shared in class, it made all of my classmates become more 3dimensional and understood." It was important to see that a student had commented on seeing other students and gaining depth on these other individuals sharing the classroom as people who have complex lives in addition to Zachary. This was a sign that this writing activity had served a higher purpose than having students practice their sentence fluency; students were gaining the awareness to learn about others including themselves through writing.

McKenna discussed how she had the dawning realization about her empathetic nature. "I think I've always been that way, so I felt as though I connected to a lot of people in my class naturally." McKenna also brought up some of the more serious life writing that students had opened up about in the class. "Now that I'm a senior, I'm surprised that we talked about something so serious, but I'm glad we did because it was all on our minds after hearing that story." McKenna is referencing the time dedicated in class to allow students to unpack the story that another student wanted to share. She finished her final thoughts by discussing a change in her maturity as well. 'I think I'm not so quick to judge now, but it wasn't until after eighth grade that I finally matured enough to figure that out. In a way, it felt a lot like therapy just by writing on those bad days." In no way is this writing a substitute for therapy, but the fact that a student 
mentioned it feeling therapeutic pointed towards the life writing and sharing activity being valuable for McKenna.

\section{Relationship Among the Codes}

One of the more interesting observations after conducting the study was seeing how the codes played off of one another. For instance, students' willingness to share would shift the most dramatically after other students would begin sharing. The pressure to share writing was most present before anyone spoke. After a student took a chance, raised their hand, and shared their writing, there seemed to be an immediate shift in participation. It felt like a barrier would come down for most students after someone had "broken the ice" by taking the risk of going first. The pressure to share ebbed away, there was an increase in the willingness for students to share. This is what led into things becoming more personal about what students chose to write about and share with the class.

Being heard was another code that was identified within the study. Students were feeling heard when they were choosing to share their writing. As more hesitancy about sharing their writing came down, more students would raise their hands so they could share. This would occasionally make it difficult for me at times to fit everyone's stories and comments into the allowed time in class. As students continued to share more, experiences of empathy began to emerge. This is an instance where Zachary opened up about his mother's cancer diagnosis and this had affected the other students sitting in the room. Students were talking about things that were deeply personal rather than sharing information some may consider to be superficial.

As students opened up about personal stories, others would begin to respond. There were students in my classroom taking those risks and making themselves vulnerable to their peers and myself. This is what led to the mutual aid and support being identified through the reflecting 
writing in the study questions. McKenna had the opportunity to talk about suicide prevention in class due to another student opening up about dealing with a family member who had passed due to a suicide. Discussions were not always this serious, but students had now become aware that by sharing, they were allowing themselves to be heard by their peers in addition to other students reaching out to provide support. We could all share, the good and the bad, and there were people in the classroom listening.

The entire idea for this study came from the day when Alex reached out to Zachary and had asked about how his mother was doing. From my perspective as the teacher, it created a shift in classroom dynamics as people seemed to come closer by sharing stories and identifying similarities and experiencing sympathy for those in the class who shared about their misfortunes. This is also where students began to get along more. There seemed to be a little more patience between students once students had been able to start sharing their life writing more so in the classroom. More conversations were being fostered in the classroom that led to serious discussions about life choices, decision making, and carefully considering the future actions of my students in the classroom.

This is also the point in the school year when I would experience less discipline issues between students. There were less vocal jabs at one another, less disruptions, and less rude remarks. From the teacher's perspective, I believed it was due to students learning more about one another and becoming more sympathetic. One example of this was when Will explained how he became less judgmental about a student who liked cars after he had learned how smart his peer was about vehicles. As these social shifts occurred, there was also a shift away from egocentricity with my eighth grade students. The more students seemed to care about others' stories in the class, the more vulnerable other students allowed themselves to become when they 
shared their life writing in class. It all became a blend of transitions where I could finally identify the beginnings of empathy occurring in my middle level classroom. It all began with students becoming willing to share their writing during class.

\section{Unexpected Findings Regarding Student Voice}

Students knew the expectations as it was a weekly routine which could contribute to the flow of the class. If students know what to do, then without even having to say anything except, "Good morning and happy Friday," students would be immediately heading towards the back of the class without being told to get their writing folders before the bell to begin class rings. Having these structures has assisted with classroom management as well. Students enjoy knowing what to do and students thrive when they understand the structure of the class and can predict the classroom patterns and procedures.

Another unexpected observation was the specific stories that students remembered. Most of them, I did recall, but some of the writing that students recorded had mentioned events that I had forgotten about. I made a mental note of how it was interesting that what I may have considered to be a small, everyday occurrence or passing comment actually meant a great deal for my students at the time. It's similar to how a student may pause, look at me, and ask, "How are you, Miss Reynolds?" It would make me pause unexpectedly and I would be happy that a student even bothered to ask, never mind the fact that they could have been asking in order to take up time in the class. Someone asked and it meant a lot to me when it may have been a small, insignificant event that many students would have forgotten about. I didn't. It makes me wonder how many small things happen in the classroom that create the same sense of being seen or feeling like their emotions, experiences, and opinions are valued. At the same time, it makes me wonder about the opposite. What small things have I done, said, or conveyed through my body 
language that has had a lasting effect on my students? It stresses the point that there needs to be mindfulness in the classroom and always that actions do have consequences, in this context being the time dedicated to students communicating their writing and valuing what they have to share.

Zachary had mentioned that his story about his mother and their struggle "came out of nowhere" in his willingness to speak about it. He had chosen to write about something deeply personal, and hadn't initially planned to share it. Although this deserves to be explored further, there was little evidence of other students experiencing this. Finding the specifics of motivation would have been interesting to explore further had more students written about it.

There were mentions of students sharing writing and valuing the process of both writing and the opportunity to share and respond to one another after the writing activity. It was encouraging to see this as a potential finding, but there wasn't enough data to expand on the idea. If more students would feel this way, there is cause for a separate analysis on what students really value in the action of writing itself and what they see as the reward of their life writing. This is an idea to be expanded on itself later to explore.

Lastly, there had been the initial expectation that students would see the therapeutic value in life writing. I was curious to see if there would be that recognition from students or them conveying that writing and sharing life writing would be healing or cathartic in some matters. Although McKenna had made an exciting comment about how this writing activity felt like therapy, there wasn't enough data to explore that hypothesis further. 


\section{Answering the Big Question}

How did these students create an empathetic community through these experiences of shared composition in a classroom that is cognizant of the need to promote students' sense of community, agency, and voice? The answer is that it's a complex recipe that requires layers of scaffolding, modeling, and establishing expectations from the instructor. A few aspects for students need to occur in order for the transition for students to feel inspired, encouraged, and secure in their ability to create this empathetic classroom through the sharing of their writing with the class. These aspects come down to three components: students being allowed time for this activity to become normalized and become part of a routine for students, students seeing instructors model the proper behavior for students during the activity each and every time the writing and sharing activity occurs, and students must have previously established a rapport with the instructor of that class.

\section{Designated Time}

Time is critical. Establishing a clear, structured time that is specifically dedicated to students knowing they have the opportunity is the first step. In my classroom, my students know that writing and sharing takes place on Fridays at the beginning of the class. Students get into the routine and habit of knowing their expectations at the beginning of that first week in the first quarter. With this activity as a constant, the first step is accomplished as students know that there is the opportunity to write and speak. Normalizing this activity through repetition, expectations, and practice can cause students to perceive this activity as less of a social risk as it becomes more familiar to them. Eventually, students come in on Fridays and, without being asked, know to obtain their writing folders. We get to the point in the school year where a student may say, 
"Hey, it's Friday!" and another student will pop out of their seat and say, "Oh!” as they hustle to grab their writing folder.

\section{Modeled Behavior Expectations}

The next step is for students to see what this interaction should look like. Students need to be able to practice their active and engaged listening skills. The teacher must be able to model these skills without being dismissive to what students have to say. This means eye contact that is comfortable for the student. The teacher is not checking their email or performing other dismissive passive listening behaviors. Students will pick up on that and then think it's alright to be dismissive themselves as the teacher is doing it during class. When dismissive listening is taking place, the speaker's words can be taken out of context without a listener's full attention or another comment is made on what a speaker said. Therefore, students need to see this interaction from the teacher as well. Keeping words respectful and on topic are some of the most important responses to practice with students. As soon as middle school students feel as though their own thoughts, opinions, or ideas are being dismissed or taken out of context by others, students can shut down or not feel the need to participate. This could potentially take away from students being active and empathetic listeners themselves to other students who wish to speak. Without these modeled behaviors, the entire experience could be viewed as a "high risk" for a student's social status. Once students can see what this modeled behavior looks like, then students can begin to take those same social risks in class, but now identified as "low stakes." Eventually, students will become accustomed to the pattern of writing, sharing, and responding, however, there needs to be constant modeling and guidance provided by the teacher for the entire classroom population to benefit from the weekly life writing activity. 


\section{Building Rapport}

The final step for middle school students to engage in the sharing of life writing as a means of developing an empathetic community between the students and the teacher in the classroom is to develop a rapport with one another. Again, this rapport will need to begin developing early on in the school year. It will be up to the teacher on how to achieve this, but can begin with simple acts of kindness and consideration. Acts like this include knowing students' names, greeting students when they enter the classroom, giving a farewell to students at the end of class. Opening up the opportunity for students to know that a teacher is invested in them as a person, not just as a student who needs a grade, is a great way to establish ethos with students.

Once that trust has been established, it can be strengthened over time as students begin to chat or engage in a dialogue with the teacher. Students should notice that the teacher is showing genuine interest in the abilities, social interest, and passions that they have. Students will be able to engage more with a class when a teacher is mindful of students' states of mind in class as supported by Dr. Brianna Kennedy. The classroom community can be improved significantly if the students feel cared for. This rapport is what can blossom into a successful group of writers who can write, share, and build off of what one another has to say in a meaningful manner. With these key features established in a classroom early on, students will contribute to a more successful and empathetic writing classroom community overall. 


\section{CHAPTER V: CONCLUSION}

\section{Teaching Applications}

As a teacher, I'm always wanting my classroom to run smoothly. I recognize that having middle school students who can demonstrate levels of empathy creates a better classroom environment for everyone involved. This study was to find an answer as to how I can create experiences for students in my classroom that allow them to grow into empathetic, caring individuals through writing. This study was conducted to see if I could support my theory that incorporating life writing habitually into a writing curriculum at the middle level could foster an empathetic classroom environment in which students will feel safe, confident, and encouraged to write and discuss their compositions with others in the class. Another, more selfish reason for this study involved the ever present worry that I have as an educator: Did my eighth grade writing class leave a lasting impact that mattered to my students? Did any of it matter to them? The answer is that it is ultimately up to the students when that comfortability takes place, however, there are a few key aspects in a classroom that can be identified when seeing this transition to feeling secure and safe in a classroom setting to begin to share writing, opening up the opportunity for students to practice their empathy, active listening, and speaking skills in front of an audience. Those elements include: established time for life writing in class, modeled behavior from the instructor, and establishing a good rapport with students.

An additional goal of this text was to present a means of practice to other educators who wish to implement these practices into their own classroom with the goal of creating a more empathetic environment for their students. I want other teachers to be able to read this study and be able to use life writing to benefit their own classrooms. It all came down to my basic 
questions: What events occurred to cause my students to share their writing? The other question being, how can I continue to promote this classroom environment that can allow students to become comfortable with sharing their writing next year? The answer is to let students write, allow students to have time specifically dedicated to writing, and provide the opportunity to share. It is important to respect their wishes if they don't wish to share. However, it's additionally important for students to know that they have the space to share if they feel the need to.

Allowing students to feel comfortable engaging in an open dialogue in a classroom with their instructor and peers were essential in building this classroom based on student feedback I received from my former students in answering my research question: In a classroom designed to promote students' sense of community, agency, and voice, how did students create an empathetic community through the experiences of shared composition?

I will continue to use life writing in my classroom as I've made a lot of progress with my own students each year. By following my methods of allowing students to share their writing and not forcing them, I know that my students will eventually open up which allows their peers to learn about others and experiences that are not their own. Some students may take time to open up and that's okay. I know that they will still be writing. Some of them will share their writing with me if they don't want to share it with the entire class. This is also a valid way to share until they're ready to speak. The nice addition to the weekly writing activity is that it also allows me to learn about my students as well as I'm also an audience member. This helps me to invest in my students which shows that I listen to what my students say. I know that I care about my students, but my students don't always know that. When I can remember and relate to something my students say, I can see it register on their faces that I have invested time in them. I remember what they say. I see them. In this way, life writing allows this mutual respect to begin with me 
and my students as well. This is what leads to less classroom management issues during class time. This is due to these professional relationships being built off of trust that is established from the very beginning of the school year and building that trust over shared experiences throughout the entire school year.

From the information, data, and codes I've received, I will continue to incorporate life writing into my curriculum in some format for any and all students that I teach. I continue to observe the shift in my own classroom and I see the value of the weekly activity. Seeing the shift in social dynamics slowly over the course of a school year is one of the most interesting and encouraging observations I've encountered as a teacher with a group of students. By continuing to see this shift in openness to others' thoughts, ideas, beliefs, and opinions, I can only continue this activity with my middle school students who desperately need the practice of engaging others in discussions who are unlike them. I am eager to see where this research takes me as I realize there is a next step I need to take where the sole focus of the research should be on voice and student autonomy of students. I know there is value in the time dedicated to this activity through written expression, and I feel like I'm one step closer to helping other teachers understand the great importance this type of writing can have on adolescents within the classroom. This entire experience has had a significant impact on my pedagogy as an educator. One of my personal takeaways from this study has been the significance of students feeling seen by their peers and instructor. From the teacher's point of view, I also wholeheartedly feel that I teach better when I feel seen by my students too. 


\section{A Conversation: Putting the Findings to Research}

I wanted to address building empathy exercises within a classroom, which is addressed in Educating for Empathy as Nicole Mirra suggests that, "us teachers, whether we are just beginning our careers or working as seasoned veterans, to consider the commitments and values that guide us as we decide which literacy practices to introduce to our students," (88). What I wanted to emphasize was the significance that writing can take in an exercise to begin to build that empathy in a classroom and help students make social-emotional connections to one another. I would like to contribute to one of the mentioned literacy practices to be incorporated into this commitment to guide students by being models of empathy, ourselves, through the Friday writings that have taken place in my classroom.

The goal was to specifically perform this case study through the lens of life writing in an ELA class at the middle level. This was especially pertinent for this level of education as some students may not have developed the cognitive ability to empathize fully with another individual due to their current brain development. Again, the Organized Developmental Mismatch Hypothesis is best described as what could affect what is perceived as a rewarding risk taking experience for adolescents, (Mills K).

The main findings throughout the writing surveys showed a number of patterns that the majority, if not all, of the students who answered the questionnaire mentioned in their writing. The first interesting note to mention was that while some of my students claimed that they had or had not been asked to share writing, no students said they had ever felt forced to share their writing. The pressure to write and share that writing in the classroom was included in the questionnaire to be mindful if an educator had ever forced a student to share which may have damaged their confidence or desire to open up and share writing in the first place. Had the 
sample size been bigger, with a larger student body to assess, I anticipate this answer may have been different with a few comments on criticizing class time usage or students feeling disengaged, regardless of that not occurring in the present data collected.

Another finding was focused on the shared writing experience. The goal was to figure out if students enjoyed the sharing of life writing or not. The intention was to connect an activity that was enjoyed which may foster the desire to share and build a learning environment that encourages students to open up about their lives and share rather than students feeling pressured and uncomfortable. The shared writing experience was overwhelmingly seen as valuable from students, but there were reservations on students sharing information and stories about themselves. Most notably, students mentioned that they enjoyed sharing their writing once they became comfortable with it, as in, they needed a prior student to have shared to gauge how the reaction of the class went. Once deemed a "safe risk," students would open up and participate in sharing their writing with the encouragement that they would feel "on about the same level," (Will) as their classmates.

An additional finding was focused on a shift in peer perceptions. I was curious to see if students were going to pick up on the same dynamic shifts taking place in the classroom as I had observed as their writing instructor. These findings were more focused on the students not thinking about themselves but considering the others in the class. As this focused on students to think about the classroom as a group, the social and emotional dynamics were deemed the most important to the case study. I wanted to know if students also felt the class beginning to share levels of empathy when it had not been present at the same level beforehand. Students may not have picked up on the empathy, but similar notes were mentioned. From comments such as "understanding one another to a higher degree," (Will) to, "our class began to respect each other 
more just because we learned about some of the things that people were going through," (Erin) all identified a shift in peer perceptions. The students were perceptive and actively noticed this change.

The final finding was an important mention of self-reflection that students had written. The goal was to measure if they had identified personal growth or reflection on their time in middle school as a writer in their language arts class. Students then provided information on themselves. A few students mentioned that they had grown in maturity as well, now that they were in high school, in order to justify why the students had not had this opportunity for growth prior to middle school. The students all claimed that they had grown as individuals for the better with many phrases such as, "I gained more confidence to talk the more time went on," (Erin) or, “in a way, it felt a lot like therapy just by writing on those bad days," (McKenna).

As the focus has been mostly on my middle school students, I would like to point out that I was not a passive bystander, and I also became part of this culture as students opened up and shared their life writing in class. As students opened up, I was also transformed. I allowed myself to be more vulnerable in my own shared experiences, even opening up about my own poor experiences or shortcomings with writing to my students. In my experience, I've learned that sometimes, comments from middle school students shouldn't be taken to heart as their words can come off as dismissive or judgmental. Gradually, as students get to know you, these pre-teen comments begin to soften with patience and kindness. Once that was established, I was able to open up more with my students as well that helped students make a stronger connection with me in addition to their peers. This evolution of my own teaching strategies was not in the forefront of my mind, but upon reflecting, I realized that I now teach differently with the hopes that I can observe my students building these collaborative and emotionally supportive relationships. I felt 
that students slowly began to look at me as a human with my own stories, experiences, and emotions rather than an authoritarian creature that teaches during school and hibernates during summer vacation.

For any elementary teachers who wish to know more, there is a dissertation that focuses on developing empathy in an effort to support elementary school students in New Jersey through their curriculum, specifically through literacy. As the students are younger, the use of picture books is used in favor of life writing. However, the picture books depict oftentimes relatable problems that elementary school children face. The use of literacy skills and social awareness from the picture books is what teachers use to promote empathy in their students. "Taken together, quantitative and qualitative findings from this research suggest that although students showed evidence of empathy learning and engagement during the intervention, they did not fully internalize empathy by the end of the intervention. This research study suggests next steps and possible future research that could be useful to support students' continued empathy development," (Salay). This is where life writing could come in as the intervention to continue that empathy development and refinement. As a middle level educator, I would support any effort made by elementary educators to use their ELA curriculum to establish an empathetic mindset. It can be difficult to establish appreciation, consideration, and understanding for other cultures and those who differ from my students at the middle level. If practice for students to experience empathy can be established through early storytelling, it could make the transition to life writing to foster empathy easier. This connects to what John had written about when talking about sharing writing in elementary school. "I just didn't care. I didn't see the point of what we were writing about." If a student doesn't understand the goal, it can make it more challenging for students to learn and appreciate the purpose of the activity. 
For educators instructing high school students, there is an article from the Journal of Adolescent and Adult Literacy, "Development of Empathetic Responses with Multicultural Literature," in which a study was conducted "to study a high school teacher's attempt to enhance students' development of empathy while reading multicultural literature after engaging them to explore the cultural, political, and historical context of the text," (Louie 567). The text was a Chinese novella written by Feng Jicai and translated from Chinese titled Let One Hundred Flowers Bloom (Feng, 1995). The text is “about an innocent artist's suffering and endurance during the decade-long Chinese Cultural Revolution beginning in 1966," (Louie 570). By the end of the six-week study, it was concluded that only a few students were willing to allow themselves to experience the feelings of others in order to truly experience empathy. "Although we could not force empathy upon the students, we provided contextual information, literature, and discussion opportunities to help students assume the literary characters' positions, which reflected the characters' socio-political background, their cultural norms, and their social values. Students questioned profusely as they adjusted themselves to see the world through the characters' lenses," (Louie 577). However, the study also concluded that it was a step in the right direction. As much as the studies seem to only be steps to establishing empathy through writing, students from my study seemed to have caught on to the writing activity we did weekly in their eighth grade year. McKenna had written about the writing activity at the high school level. "We [the class] talked about bigger issues in high school in Mr. Cowgill's [high school ELA instructor] class and how it can be used to write quickly to get our thoughts and ideas. It reminded me of power writing we used to do," (McKenna). 


\section{Future Research}

After looking at all of the studies as "steps in the right direction," it seems that there is a larger study that could potentially be conducted at a much larger scale and over a long time period. If an entire district dedicated to using curriculum to establish empathy, there is a possibility that the elementary and middle school level could scaffold and strengthen expectations as practice for students. When those students get to the high school level, students would potentially be more receptive to experiencing empathy through their written expression. The students would have already practiced identifying other perspectives through elementary school with picture books and their stories. This would teach students to understand the character's perspectives in stories. In middle school, students would be given the opportunity to strengthen their writing and sharing skills by communicating experiences that have occurred to them. It would be during this time that middle school students would additionally be able to listen to peers who they share a classroom with. These would be individuals that students know as real people with real life experiences that differ from their own. Essentially, middle school would be the shift from fiction to real life. This is what could lead to the blending at the high school level of nonfiction literature being used to understand the perspectives, feelings, and challenges of others. This would also work in works of fiction at the high school level that work as an allegory for true events that others experienced. If those were to be blended, I am curious as to the results in the levels of empathy expressed by those students. It would be my hope that those "steps in the right direction" would be more substantial.

Regardless of the elementary study and high school study only having a few students begin to show the emotional shift in understanding the way that others feel, having middle level learners practice feeling and showing empathy through writing about themselves and hearing 
about others experiences is an additional step in helping students develop empathy. There is a need to continue to study the ways in which teachers can support their students in building empathy through the arts that we teach. Life writing is my step at the middle level to begin to bridge the gaps between students being able to relate with others within picture books to analyze the ways in which lives can have stark contrasts to their own through multicultural literature. There are strides that need to be taken as life writing and its effect on middle level students is limited. The ways in which it can help students develop social-emotional awareness needs to be expanded upon.

To further continue this study, I would look to gather student data from a larger sample size to truly get an idea if life writing can be pedagogically used as a means of developing empathy and a sense of belonging for students, while keeping the focus on the middle level. An additional goal would be to see if this life writing activity can help open up dialogue with students on social issues dealing with gender, sexuality, and equality. One of the clearest pieces of data was the significance of building memories with students. If educators offer students an opportunity for an engaging learning experience, while building up those memories, students will take that opportunity to learn academically in addition to practicing how to treat others with kindness. This type of study would be interesting to build into high school as a continuation of the study. Seeing how high school students decide to write and share their experiences could additionally be beneficial to understanding how students develop empathy for their academic peers.

My current findings support my theory that incorporating life writing habitually into a writing curriculum at the middle level will foster an empathetic classroom environment in which students will feel safe, confident, and encouraged to write and discuss their compositions with 
others in the class. I am curious as to how the results would turn out if the same life writing activities were to be incorporated at the primary and secondary level of education, as middle school students weigh risks differently with the invisible audience and peer pressure taking a toll on their self-image and confidence level depending on the day. Social anxieties and the invisible audience being "proposed that imaginary audience concerns are provoked by two types of selfconsciousness: the "abiding self," which stems from excessive concerns about permanent aspects of the self, such as personality or intelligence, and the "transient self," which reflects anxiety about temporary aspects of the self, such as a bad haircut," (Kelly et al.).

Some points need to be speculated on how the data could have been very different. The brain development that deals with these transitory periods in which students weigh these risks could shift exponentially throughout their middle school career. This could affect at what time students are willing to let themselves identify sharing their writing as a "less risky" experience. As all of my students were focused on their eighth grade school year, I also anticipate a differentiation of results had I focused on the students' sixth grade year of middle school, when they were still new to the middle school building and hadn't had time to build that academic confidence.

There is another point to be made on how the data could have varied greatly. Although it was not mentioned within the findings, not all of the students that participated considered themselves to be heterosexual. A student in particular had come out to me at the beginning of their eighth grade year, which was only due to the fact that I had built up a rapport with that student their seventh grade year. I believe it is the trust that was built up that allowed that student to feel comfortable opening up to me over coming out to their parental figures. The concept of life writing and sharing is meant to establish shared experiences between others in addition to 
opening up opportunities for participants to learn and understand more about people who are different than our own. This writing and sharing activity could warrant a future study on the experiences of students of any age level who identify as an individual who is part of a community that is ostracized or oftentimes left out of discussions. This includes students of color, members of the LGBTQA+ community, non-binary or trans students, students who practice a religion other than Christianity, or consider themselves to be agnostic or atheist, or students who come from different socio-economic backgrounds. One of my students had mentioned how they were grateful for being adopted, but there wasn't enough information to continue with the concept, however, this could also apply to students who don't live with a biological parent.

I believe that this writing activity could be considered high risk when it comes to sharing from students who are a part of one or more of these communities. There may be the desire to come out or to let people know that they are different as a lot of middle school students are trying to pinpoint their identity, yet there may be some hesitation when it comes to sharing. This could be due to how others in the class may be judgmental due to their upbringing in their household. This is where modeling comes in best for teachers as some students may want to speak against these communities. It is imperative to establish acceptance, kindness, and continuous discussions with students when it comes to those who are different. This could be especially helpful in students who may have beliefs that are prejudiced against others. By having students learn about others, especially when it's people who are familiar, I believe can help students become more accepting of others because they have established a positive connection to someone who is unlike them. By having the unknown or "Other" become more familiar, students can continue to practice establishing sympathy and empathy for people who are different from 
themselves. This is what I believe could lead to students growing into adults who can accept others who are different and be able to work with people from various backgrounds. A study conducted on life writing and sharing in connection with students who identify as a member of one of more of these communities as participants may reveal new and different knowledge on how educators and districts can better support our students who are members of these communities while also addressing the student body that may be a threat to these minority groups.

This work was written to capture a specific moment in my teaching career that has had significant meaning to me as a writing instructor of middle school students. With this case study, I am now more grounded in both my philosophical and pedagogical views when it comes to creating a classroom environment that supports students in the sharing of writing. It is with encouragement from my fellow educators and support from my students that I continue discussing the benefit and value of life writing and sharing that life writing in the classroom with others. 


\section{WORKS CITED}

“ARGENTA-OREANA CUSD 1: District Snapshot.” ARGENTA-OREANA CUSD $1 \mid$ District

Snapshot, www.illinoisreportcard.com/district.aspx?districtid=39055001026.

Arowosafe, Donna Schumacher and Judith L. Irvin (1992) “Transition to a Middle Level School: What Kids Say," Middle School Journal, 24:2, 15-19, DOI:

10.1080/00940771.1992.11495162 Accessed 24 Feb. 2021.

Atwell, Nancie. In The Middle: New Understandings about Writing, Reading, and Learning. Portsmouth, NH :Boynton/Cook, 1998.

Behizadeh, Nadia. "Aiming for Authenticity: Successes and Struggles of an Attempt to Increase Authenticity in Writing." Journal of Adolescent and Adult Literacy. 11 September 2018. Wiley Online Library, https://ila.onlinelibrary.wiley.com/doi /abs/10.1002/jaal.911. Accessed 17 Sept. 2020.

Louie, Belinda. "Development of Empathetic Responses With Multicultural Literature." Journal of Adolescent and Adult Literacy, vol. 48, no. 7, Apr. 2005, pp. 566-578. EBSCOhost, search.ebscohost.com/login.aspx?direct=true \&db=eric\&AN=EJ68 4326\&site=ehost-live\&scope=site. Accessed 15 Mar. 2021.

Charmaz, Kathy. Constructing Grounded Theory: A Practical Guide Through Qualitative Analysis. London: Sage Publications, 2006. Print.

Daily, Shay M., et al. "Using School Climate to Improve Attendance and Grades: Understanding the Importance of School Satisfaction among Middle and High School Students.” Journal of School Health, vol. 90, no. 9, Sept. 2020, pp. 683-693. EBSCOhost, search.ebscohost.com/login.aspx direct=true \&db=eric \&AN=EJ1264943\&site=ehostlive\&scope=site. Accessed 17 Sept. 2020. 
Feldman. RTI Action Network. The National Center for Learning Disabilities, Inc: 2004. rtinetwork.org/. Accessed 09 Dec. 2020.

Galati, Rhea, et al. Upcountry Stories: Students Serve through Writing. Linking Learning with Life. Jan. 2001. EBSCOhost, search.ebscohost.com/login.aspx?direct=true\&db=eric \&AN=ED459459\&site=ehost-live\&scope $=$ site. Accessed 9 Dec. 2020.

Hall, Anna H. "Beyond the Author's Chair: Expanding Sharing Opportunities in Writing." Reading Teacher, vol. 68, no. 1, Sept. 2014, pp. 27-31. EBSCOhost, search.ebscohost.com/login.aspx?direct=true\&db=eric\&AN=EJ1036962\&site=ehostlive\&scope=site. Accessed 12 Nov. 2020.

Kelly, K. M., Jones, W. H., \& Adams, J. M. (2002). "Using the Imaginary Audience Scale as a measure of social anxiety in young adults." Educational and Psychological Measurement, 62, 896-9. Accessed 17 Oct. 2020.

Kennedy, Brianna L. "Teaching Disaffected Middle School Students: How Classroom Dynamics Shape Students' Experiences.” Middle School Journal (J3), vol. 42, no. 4, Mar. 2011, pp. 3242.EBSCOhost, search.ebscohost.com/login.aspx?direct=true\&db=eric\&AN=EJ917472 \&site=ehost-live\&scope=site. Accessed 17 Oct. 2020.

Lorain, Peter. "Can't Stop Talking: Social Needs of Students in the Middle.” NEA, 2002, www.nea.org/tools/16641.htm. Accessed 16 June 2020.

McNish, Barbara. "Spirit of Healing Group: Safety in Storytelling." BU Journal of Graduate Studies in Education, vol. 5, no. 2, Jan. 2013, pp. 41-45. EBSCOhost, search.ebscohost.com/login.aspx?direct=true $\& d b=$ eric $\& A N=E J 1230752 \&$ site=ehostlive\&scope=site. Accessed 16 June 2020. 
Mills K, L, Goddings A, -L, Clasen L, S, Giedd J, N, Blakemore S, -J: “The Developmental Mismatch in Structural Brain Maturation during Adolescence.” Dev Neurosci 2014;36:147-160. doi: 10.1159/000362328.

Mills, Kathy A. Literacy Theories for the Digital Age: Social, Critical, Multimodal, Spatial, Material and Sensory Lenses. Multilingual Matters, 2016.

Mirra, Nicole. Educating for Empathy: Literacy Learning and Civic Engagement. New York, NY: Teachers College Press. 2018.

NMSA/AMLE. This We Believe: Keys to Educating Young Adolescents. Westerville, OH: Association for Middle Level Education. 2010.

Palmeri, Jason. Remixing Composition: A History of Multimodal Writing Pedagogy. Carbondale: Southern Illinois University Press, 2012. Print.

Robillard, Amy and D. Shane Combs. How Stories Teach Us: Composition, Life Writing, and Blended Scholarship. Peter Lang, 2019.

Rose, Suzanne M. “'If Only It Weren't Such a Chore...': What Talented Eighth Graders Have to Say about Their ELA Classes.” Voices from the Middle, vol. 18, no. 3, Mar. 2011, pp. 18-26. EBSCOhost, search.ebscohost.com/login.aspx?direct=true\&db=eric\&AN $=$ EJ917444\&site=ehost-live\&scope=site. Accessed 13 Feb. 2021.

Rosenfeld, Lawrence B. "I Felt Filled by the Experience, as If Writing the Narrative Gave Me a Piece of My Own Life": Appraisals of a Personal Narrative Assignment in a Family Communication Course. Nov. 1993.EBSCOhost,search.ebscohost.com/login.aspx?direct $=$ true $\& \mathrm{db}=$ eric $\& \mathrm{AN}=\mathrm{ED} 367036 \&$ site $=$ ehost-live $\&$ scope $=$ site. 
Salay, Darla M. "Walk in Their Shoes: How Picture Books and Critical Literacy Instruction Can Foster Empathy in First Grade Students.” ProQuest LLC, ProQuest LLC, 1 Jan. 2018. EBSCOhost,search.ebscohost.com/login.aspx?direct=true\&db=eric\&AN=ED585351\&sit e=ehost-live\&scope=site. Accessed 14 Mar. 2021.

Shipka, Jody. Toward a Composition Made Whole. University of Pittsburgh Press, 2011. JSTOR, www.jstor.org/stable/j.ctt5hjqkk. Accessed 21 Apr. 2020.

Smith, Sidonie and Julia Watson. A Guide for Interpreting Life Narratives Reading Autobiography. 2nd ed., University of Minnesota Press. 2001.

Turner, Bret. "Building Classroom Community through Storytelling." Educational Leadership, vol. 76, no. 1, Sept. 2018, pp. 72-76. EBSCOhost, search.ebscohost.com/login.aspx?direct $=$ true $\& d b=$ eric \&AN=EJ1190815\&site=ehostlive\&scope $=$ site. $($ Feldman). Accessed 16 June 2020.

Wimer, Kathy. Personal interview. 18 December 2020.

Yao, Zhuojun and Weiming Luhb. "A New Longitudinal Examination on the Relationship between Teaching Style and Adolescent Depression.” International Journal of Psychology and Educational Studies. Vol 6 no. (1), 1-9. IJPES, 2019. https://files.eric.ed.gov/fulltext/EJ1208342.pdf. Accessed 13 Feb. 2021. 


\section{APPENDIX A: FIRST ROUND DATA GATHERING QUESTIONS}

Kristin Reynolds

Life Writing Questions for Former Students

$10 / 19 / 19$

\section{DIRECTIONS:}

Read the three questions below. You can offer as much or as little detail as you want. These questions are with the focus being on recalling middle school, but feel free to talk about other experiences from high school having to do with writing. Don't worry about being fancy with your writing or your grammar. This is all about YOUR experience with writing and sharing writing in the classroom.

The last day to fill out and submit these questions will be: Sunday October 27th.

1.What has been your experience in life writing?

Answer:

2. Why do we use life writing in the classroom?

Answer:

3. What kind of community can be built through writing and discussing together as a group?

Answer: 


\section{APPENDIX B: SECOND ROUND DATA GATHERING QUESTIONS}

Kristin Reynolds

Life Writing Questions for Former Students

$11 / 30 / 20$

\section{DIRECTIONS:}

Read the two questions below. You can offer as much or as little detail as you want. These questions are with the focus being on recalling middle school, but feel free to talk about other experiences from high school having to do with writing. Don't worry about being fancy with your writing or your grammar. This is all about YOUR experience with sharing writing in the classroom. If you would like to elaborate on a specific question, we can always set up a Google Meet.

The last day to fill out these questions will be: Thursday December 17th.

1.Can you describe a past experience when you've been asked to share your writing with a class? How were you asked to share? Did you feel comfortable with this experience? How did that experience make you feel? Did it go well or poorly? Please give as much detail as possible. If you have multiple experiences you wish to write about, please do.

Answer:

2.Describe how you believe students' sharing their writing affected the classroom community. Were any classroom relationships affected by this sharing of writing about life experiences? Do you recall any shifting in positive/negative relationships (significant others, friendships, peer relationships) as more students shared their writing in the classroom setting?

Answer: 